\title{
Belt-Parallel Shortening in the Northern Apennines and Seismotectonic Implications
}

\author{
Marcello Viti' ${ }^{1}$, Enzo Mantovani ${ }^{1}$, Daniele Babbucci ${ }^{1}$, Caterina Tamburelli' ${ }^{1}$, Nicola Cenni ${ }^{2}$, \\ Massimo Baglione ${ }^{3}$, Vittorio D'Intinosante ${ }^{3}$ \\ ${ }^{1}$ Dipartimento di Scienze Fisiche, della Terra e dell'Ambiente, Università degli Studi di Siena, Siena, Italy \\ ${ }^{2}$ Dipartimento di Fisica ed Astronomia, Università degli Studi di Bologna, Bologna, Italy \\ ${ }^{3}$ Settore Sismica, Regione Toscana, Firenze, Italy \\ Email: marcello.viti@unisi.it
}

Received 15 June 2015; accepted 28 August 2015; published 31 August 2015

Copyright (C) 2015 by authors and Scientific Research Publishing Inc.

This work is licensed under the Creative Commons Attribution International License (CC BY).

http://creativecommons.org/licenses/by/4.0/

(c) (i) Open Access

\begin{abstract}
Major seismic activity in the Northern Apennines concentrates in few zones, distributed in a peculiar way. It is argued that such context may be plausibly explained as an effect of belt-parallel shortening, which has caused oroclinal bending of the longitudinal ridges formed during the Late Miocene to Lower Pliocene evolutionary phase. The main effects of this process, developed since the upper Pliocene, have mainly affected the outer sectors of the belt. The major seismic sources have generated in the zones where different oroclinal bendings of adjacent ridges have produced extensional/transtensional deformation. In the inner side of the Northern Apennines, belt parallel shortening has occurred at a lower rate. The main effects have resulted from the shortening of the Albano-Chianti-Rapolano-Cetona ridge. In particular, the proposed tectonic setting may account for the moderate seismic activity that occurs in the Firenze, Elsa, Pesa, Siena and Radicofani basins.
\end{abstract}

\section{Keywords}

Northern Apennines, Seismotectonics, Oroclinal Bending

\section{Introduction}

The distribution of seismic sources in the Northern Apennines (Figure 1) is rather heterogeneous, with zones of high activity separated by almost aseismic areas. Here we discuss on how this peculiar feature may be connected with the recent-present tectonic setting.

How to cite this paper: Viti, M., Mantovani, E., Babbucci, D., Tamburelli, C., Cenni, N., Baglione, M. and D'Intinosante, V. (2015) Belt-Parallel Shortening in the Northern Apennines and Seismotectonic Implications. International Journal of Geosciences, 6, 938-961. http://dx.doi.org/10.4236/ijg.2015.68075 
In a number of works [3]-[10], we have discussed the geodynamic context that may generate seismic activity in the axial and outer sectors of the Apennine belt. The proposed interpretation, sketched in Figure 2, provides that such activity is mostly produced by the relative motion among the outer sector of the belt, that stressed by the Adria plate is undergoing lateral escape and uplift, and the inner less mobile zones. The escaping material only includes the sedimentary cover, decoupled from its crustal basement at seismogenic depths (of the order of $6-10 \mathrm{~km}$ ) by mechanically weak lithological horizons, as evidenced by seismic survey [11] [12] and borehole data [13]-[15]. In particular, a Late Triassic evaporitic layer (Burano formation [16]) forms the base of the Meso-Cenozoic sedimentary cover of most of the Romagna-Marche-Umbria and Toscana-Emilia wedges [17]-[20]. The overall weakness of the Burano formation is related to the presence of evaporite (anydhrite) levels among dolostones [21].

The outer more mobile belt is constituted by the Molise-Sannio wedge (MS) in the Southern Apennines, the eastern sector of the Lazio-Abruzzi carbonate platform (ELA) in the Central Apennines, and the RomagnaMarche-Umbria (RMU) and Toscana-Emilia (TE) wedges in the Northern Apennines [4]-[6] [8]. The oblique divergence between the mobile Apennine wedges and the inner, less mobile belt has been accommodated by extensional and sinistral transtensional deformation, mainly concentrated in the axial zones, where a series of continental intramontane basins has developed in the Quaternary [23]. This context has also involved compressional deformation at the outer front of the extruding wedges, where they over thrust the Adriatic domain [24].

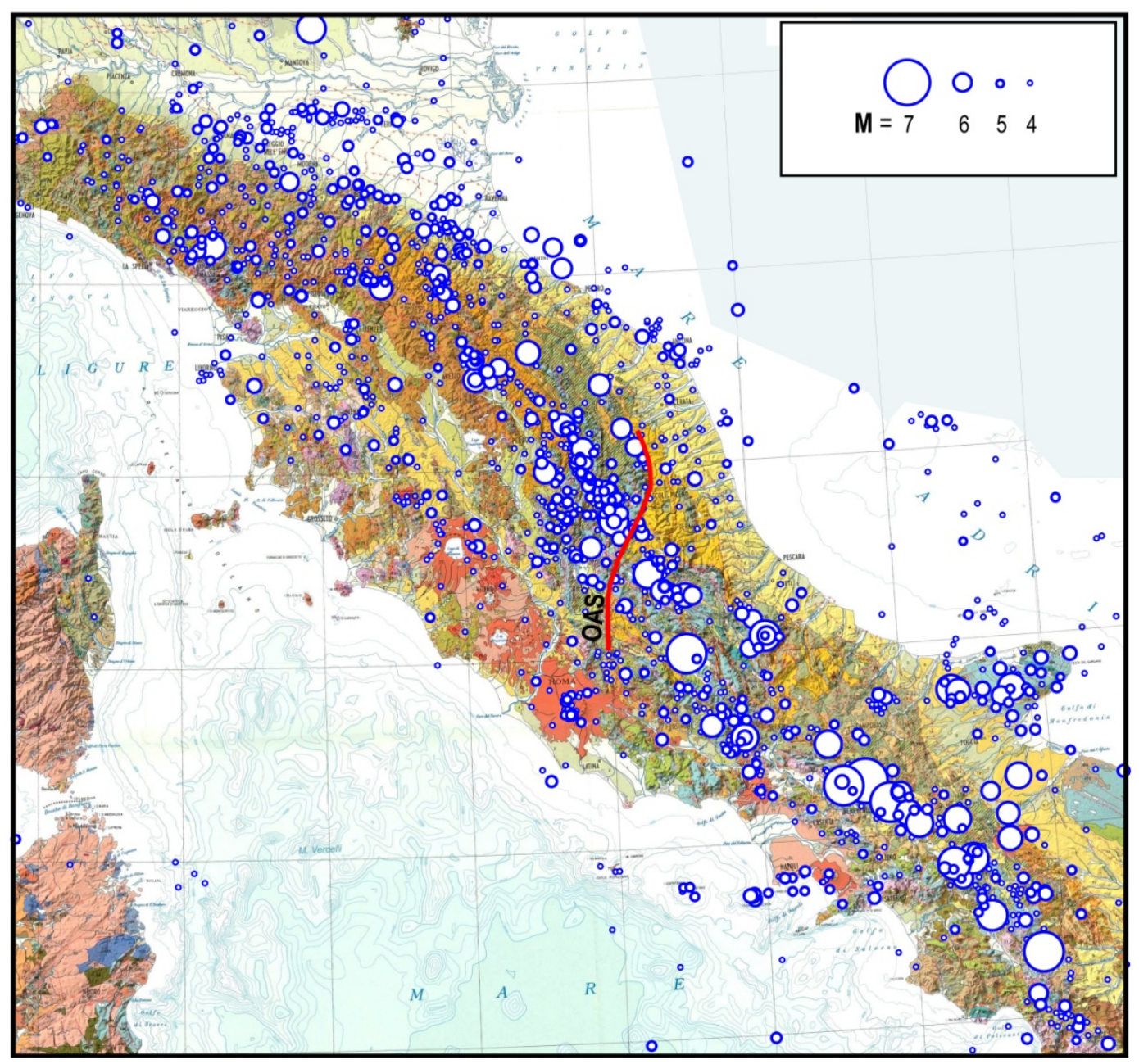

Figure 1. Distribution of major earthquakes $(M \geq 4)$ in the Apennine belt since 1000 AD. Seismicity data from [1]. The red line marks the conventionally adopted southern boundary of the Northern Apennines, i.e. the Olevano-Antrodoco-Sibillini thrust front (OAS) [2]. 
The fact that a mobility, even though slower with respect to the outer belt, also affects the inner sector of the Apennine belt, is related with the motion of the African plate, transmitted by the Calabrian wedge and Southern Apennines, as argued in previous works [4]-[8].

In Figure 2 it is suggested that the Romagna Apennines should be cut by a major transversal discontinueity, the Romagna-Forli fault system (RF). The presence of such feature is revealed by its numerous seismic activations [1]. The lack of clear morphological evidence of such fault may be imputed to its very young generation (late Pleistocene). Possible signals of the presumed fracture may be represented by a series of vertical faults which

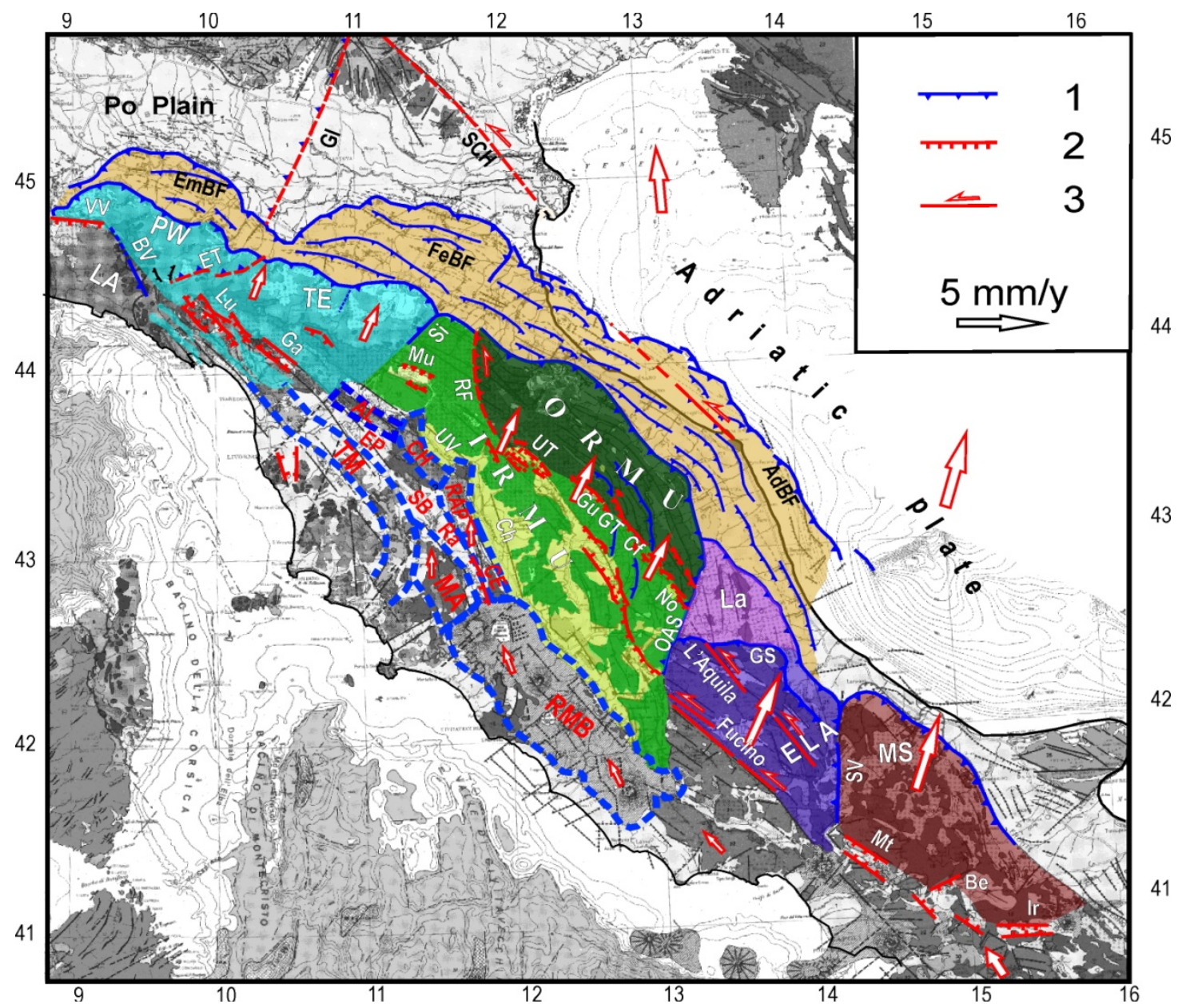

Figure 2. Tectonic sketch and post-early Pleistocene kinematics (arrows) of the Apennine belt and Adriatic plate reported on the Carta Tettonica d'Italia [22]. Colours help to identify the various elements of the outer mobile belt. See text for explanations. The Molise-Sannio wedge (MS) is dark brown, the eastern Lazio-Abruzzi wedge (ELA) is dark violet, the Laga units (La) are light violet, the outermost sector of the Romagna-Marche-Umbria wedge (ORMU) is dark green, the inner portion of the RMU wedge (IRMU) is light green, the Toscana-Emilia wedge (TE) is blue, the buried folds of the belt, lying along the Adriatic-Padanian foredeep, are light brown. The main basins lying inside the RMU wedge are yellow. Blue contours and abbreviations in the inner side of the belt (grey) identify some major elements cited in the text: Pre-Neogene ridges: $\mathrm{AL}=$ Albano, $\mathrm{CH}=$ Chianti, RAP $=$ Rapolano, $\mathrm{CE}=$ Cetona, $\mathrm{MA}=$ Montalcino-Amiata, $\mathrm{TM}=$ Toscana Metamorphic. Neogene basins: $\mathrm{Ch}=$ Chiana, $\mathrm{EP}=$ Elsa-Pesa, $\mathrm{Ga}=$ Garfagnana; $\mathrm{Lu}=$ Lunigiana, $\mathrm{Mu}=$ Mugello, $\mathrm{Ra}=$ Radicofani, $\mathrm{SB}=\mathrm{Siena}, \mathrm{UV}=$ Upper Valdarno. Fault systems: $\mathrm{Be}=$ Benevento, BV $=$ Bedonia-Varzi, ET $=$ Enza-Taro, Ir $=$ Irpinia, Mt $=$ Matese, No-Cf-GT-Gu = Norcia-Colfiorito-GualdoTadino-Gubbio, UT = Upper Tiber, VV = Villalvernia-Varzi. RF = Supposed fault system in the Romagna Apennines and Forlì zone, tentatively inferred from the alignment of strong historical earthquakes. Buried folds: $\mathrm{AdBF}=$ Adriatic, $\mathrm{EmBF}=$ Emilia, $\mathrm{FeBF}=$ Ferrara. Thrust fronts: $\mathrm{OAS}=$ Olevano-Antrodoco-Sibillini, $\mathrm{Si}=$ Sillaro, SV = Sangro-Volturno. LA = Ligurian Apennines, GS = Gran Sasso Arc, PW = Piacenza wedge, RMB $=$ Roman Magmatic Body. 1,2,3) Compressional, extensional and transcurrent features. The lines crossing the Po valley (Gi $=\mathrm{Giudi}-$ carie and $\mathrm{SCH}=$ Schio-Vicenza) indicate major discontinuities in the underlying Adriatic domain, activated during the Neogene [3]-[10]. 
cut the Miocene-Pliocene thrust fronts [25]. Such faults could be the surface expression of a deep fracture zone with a roughly S-N orientation, as the one suggested by [26] on the basis of reflection seismic surveys. In the proposed tectonic context, the generation of the above discontinuity may have resulted from the opportunity, in view of the minimum work concept, to decouple the outermost sector of the RMU wedge, almost parallel and closer to the Adria plate, from the Toscana-Emilia Apennines.

In the short-term (tens to hundreds of years), the kinematic/tectonic context described above mainly develops during and just after major decoupling earthquakes. When a strong shock occurs at the inner extensional decoupling boundary of the MS wedge (Irpinia-Benevento-Matese fault system [8] [27]-[29]) that block accelerates, increasing its belt-parallel push on the eastern part of the LA platform. This indentation induces shear stress at the sinistral transtensional faults (L'Aquila and Fucino [4] [8] [23] [30] [31]), that are located at the boundary between the stressed and non-stressed sectors of LA.

When this stress increase causes seismic activation of the L'Aquila fault, the sector of LA that accelerates is relatively narrow, being mainly constituted by the Gran Sasso Arc and the Laga units (Figure 2). Correspondingly, the sector of the RMU wedge in the Northern Apennines that is stressed by such push is narrow as well. This interpretation may explain why the major belt-parallel fault system Norcia-Colfiorito-Gualdo TadinoGubbio (No-Cf-GT-Gu in Figure 2), roughly running along the northward prosecution of the L'Aquila fault system has developed within the RMU wedge since the late Quaternary [23] [30] [32]. Such major fracture, and its possible northward prosecution in the Upper Tiber and Romagna-Forli fault systems, might represent the inner extensional/transtensional border of a wedge that will be hereafter recalled as Outer Romagna-Marche- Umbria (ORMU in Figure 2).

When, instead, seismic decoupling in the Central Apennines develops at the Fucino fault system, the sector of LA that accelerates (ELA in Figure 2) is wider. Consequently, the stressed portion of the RMU wedge in the Northern Apennines is wider as well, involving both the inner (IRMU) and outer (ORMU) wedges. More detailed considerations about the tectonic setting in the Northern Apennines and its possible Quaternary evolution are given in the next sections.

It has been argued [33]-[39] that the proposed tectonic context is compatible with the spatio-temporal distribution of major earthquakes that occurred during the main seismic crises developed in that belt since 1300 (Figure 3), as synthetically described in the following.

The first crisis (Figure 3(a)) may have started with the 1349 strong earthquake $(M=6.6)$ that occurred at the inner extensional border of the MS wedge [36]. That decoupling event has allowed the above wedge to accelerate, increasing its belt-parallel push on the eastern sector of the Lazio-Abruzzi (LA) platform (Figure 2). This dynamic context could explain why a strong earthquake $(\mathrm{M}=6)$ soon occurred at the L'Aquila fault system, allowing the easternmost sector of the LA platform to decouple and accelerate. This enhanced belt -parallel push on the RMU wedge in the Northern Apennines. As a consequence, seismic activity soon increased at the inner extensional border of this last wedge, particularly in the Upper Tiber Valley (1352, M =6.4; 1353, I = IX).

The second seismic crisis (Figure 3(b)) may have started in the Southern Apennines with two strong decoupling earthquakes (Benevento, $\mathrm{M}=7.0$ and Molise, $\mathrm{M}=7.0$ ) that struck the internal extensional border of the MS wedge on 1456. As in the previous sequence, the acceleration of this wedge might have emphasized its beltparallel push on the eastern sector of the LA platform and consequently shear stress at the major fault systems of this zone. This might explain why strong shocks occurred at the L'Aquila fault system within short time (1456, 5.8; 1461, $\mathrm{M}=6.4$ ). The consequent increase of tectonic load on the Northern Apennines, due to the acceleration of the eastern LA platform, might be responsible for the occurrence of a major earthquakes at the internal border of the RMU wedge (1458, Upper Tiber Valley, $\mathrm{M}=5.8$ ).

The third seismic crisis (Figure 3(c)) may have been triggered by three strong shocks in the Southern Apennines $(1688, \mathrm{M}=7 ; 1694, \mathrm{M}=6.8 ; 1702, \mathrm{M}=6.5)$. As in previous crises, these decoupling events were followed within few years by strong shocks in the central Apennines (1703, $M=6.7$ and 6.7 and 1706, $M=6.8$ ) that activated the L'Aquila fault system [42].

In the first three crises Figures 3(a)-(c), seismic activity, after having migrated in a few years from the Southern to the Central Apennines, progressively interested the RMU and TE wedges in the Northern Apennines, within periods even lasting several decades [5]-[7] [43].

The fourth seismic crisis in the Apennine belt (Figure 3(d)) may have started with the major earthquakes that 

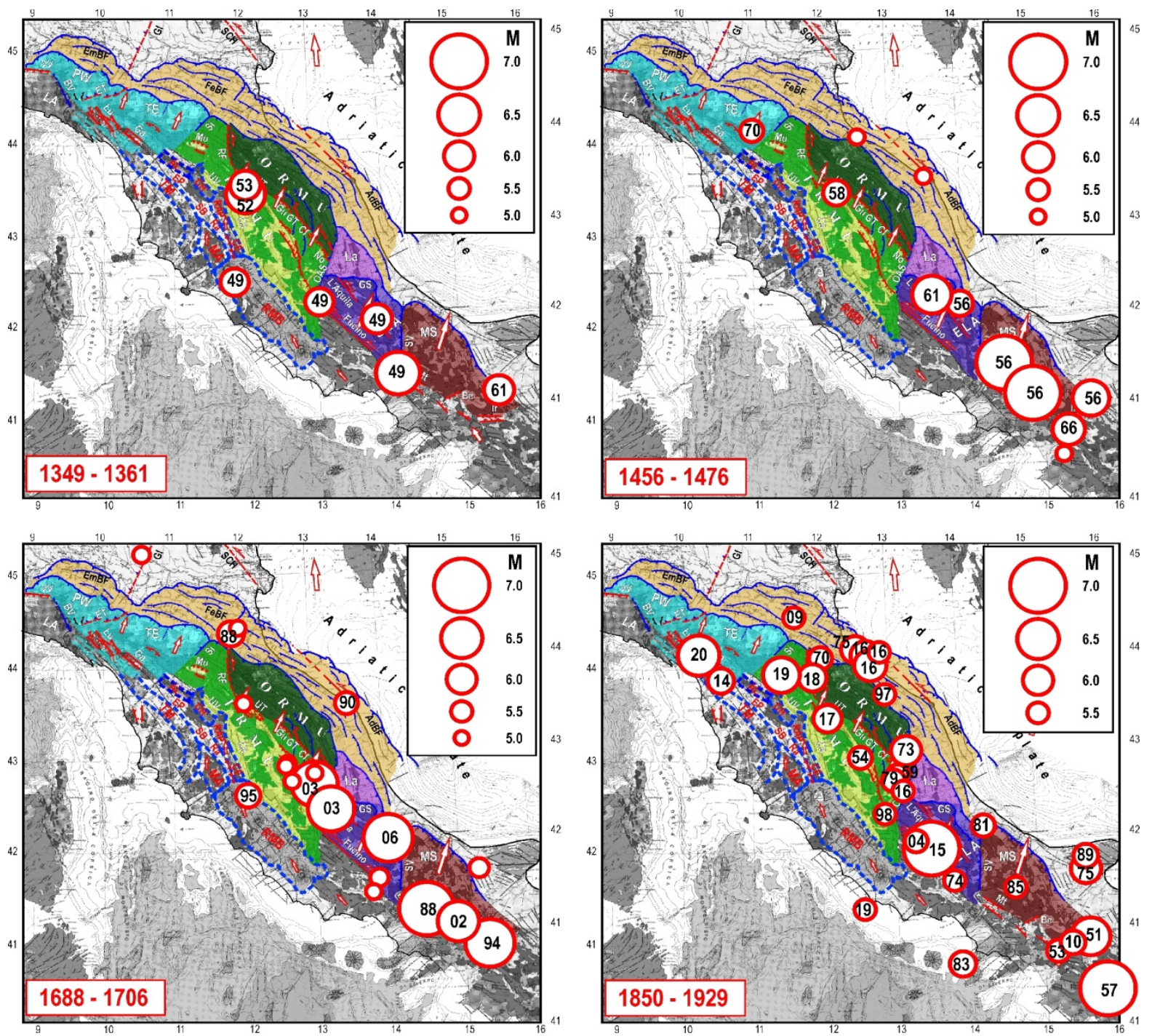

Figure 3. Main seismic crises in the Apennine belt. $\mathrm{M}=$ magnitude. Numbers inside circles indicate the year of occurrence for events with $M \geq 5.5$. See text for comments. Seismicity data from [1] [40] [41].

occurred in the southernmost part of the Molise-Sannio wedge inner boundary in $1851(\mathrm{M}=6.4), 1853(\mathrm{M}=5.6)$ and $1857(\mathrm{M}=7.0)$ [1]. However, these seismic decoupling were not followed within a short time by major shocks in the Central Apennines, in contrast with what happened in the previous crises (Figures 3(a)-(c)). Strong seismicity in the Central Apennines only occurred several tens of years later (1915), in the Fucino zone. Such long delay (and the related long strain accumulation) could explain why the 1915 event was characterized by the highest magnitude $(M=7.0)$ ever occurred in that zone (as far as we know). Such strong shock induced a considerable instability in the northern Apennines, as shown by the fact that in a relatively short time (1916-1920) several seismic zones were activated by major earthquakes (M>5.5, Figure 4).

It is worth noting that the above crisis only marginally activated the Norcia-Colfiorito-Gualdo Tadino-Gubbio-Upper Tiber fault system, which was instead involved in the previous crises (Figures 3(a)-(c)). This different behaviour may be due to the fact that the activation of the Fucino fault, involving the decoupling of a wider portion of the Lazio-Abruzzi platform (ELA in Figure 2), did not induce shear stress at the above discontinuity, which is mostly aligned with the L'Aquila fault system. Instead, the effects of the 1915 Fucino involved an acceleration of both the ORMU and IRMU wedges (Figure 2). The decoupling of the ORMU wedge from the surrounding structures was first allowed by the activation of its outer thrust front (Rimini, 1916, M =6, 6.1, 5.5). 
Then, the transtensional strain induced by this shock caused the activation of the Upper Tiber fault system (1917, $M=5.9$ ). Once decoupled the ORMU wedge from the above lateral constraints, the consequent acceleration of that wedge caused the activation of the last decoupling zone, i.e. the Romagna-Forli fault system (1918, M = 5.9). The acceleration of the IRMU wedge, triggered by the 1915 Fucino event, stressed the westernmost portion of the Northern Apennines, where the probability of earthquakes significantly increased. This could explain why in the subsequent years two strong shocks took place in that Apennine sector (Mugello, $1919 \mathrm{M}=6.3$ and Garfagnana 1920, M =6.5). Some considerations about the tectonic implications of the 1916-1920 seismic crisis are given in the next section.

A possible explanation for the timing of the major earthquakes reported in Figure 4 is provided by [35] [36], considering the results of the numerical modeling of post-seismic relaxation induced by major shocks in the above sequence.

The understanding of the possible connection between the ongoing tectonic setting and the spatio-temporal distribution of major earthquakes, tentatively developed in the studies described above, may be favoured by a deepening of our knowledge about the recent evolution of the Northern Apennines. This work describes an attempt at achieving that information. The next section concerns the outer sector of the belt, while the tectonic context in the inner side of the study area is discussed in section 3. The present kinematic pattern, inferred by geodetic observations carried out by a relatively dense network of continuous GPS stations, and its possible tectonic implications are discussed in Section 4.

\section{Belt-Parallel Shortening in the Romagna-Marche-Umbria and Toscana-Emilia Apennines}

This section discusses on how the large scale geodynamic context described in the previous section may have

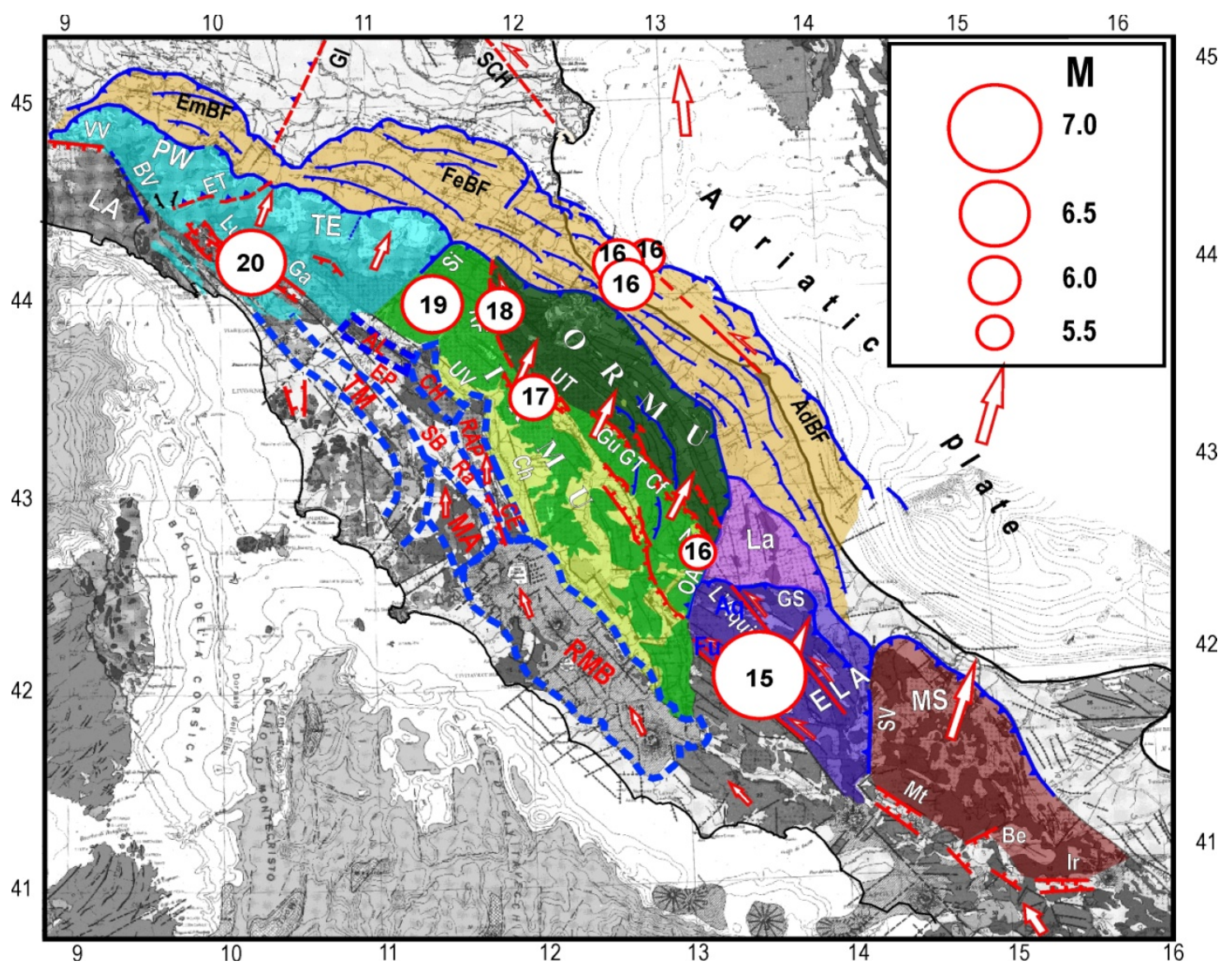

Figure 4. Distribution of major earthquakes $(M>5.5)$ in the Northern Apennines during the period 1915-1920 [1]. 
determined the complex distribution of geological and morphological features in the axial and outer sectors of the Northern Apennines. In particular, we aim at recognizing the local deformation patterns which may be responsible for the generation of the tectonic features that actually host the main seismogenetic sources in the study area, i.e. the Norcia-Colfiorito-Gualdo Tadino-Gubbio, Upper Tiber, Romagna-Forlì, Mugello, Garfagnana and Lunigiana fault systems. To better explain the proposed interpretation, a tentative evolutionary reconstruction of the Pliocene-Pleistocene deformation pattern is shown in Figure 5.

As argued earlier, the belt-parallel push of the Molise-Sannio wedge has been transmitted to the Northern Apennines by the LA platform (Figure 2). However, major evidence suggests that the sector of LA which has indented the Northern Apennines has become narrower and narrower over time, as tentatively sketched in Figure 5 .

In the Pliocene (Figure 5(a)), no major longitudinal decoupling fault system was active in the LA platform

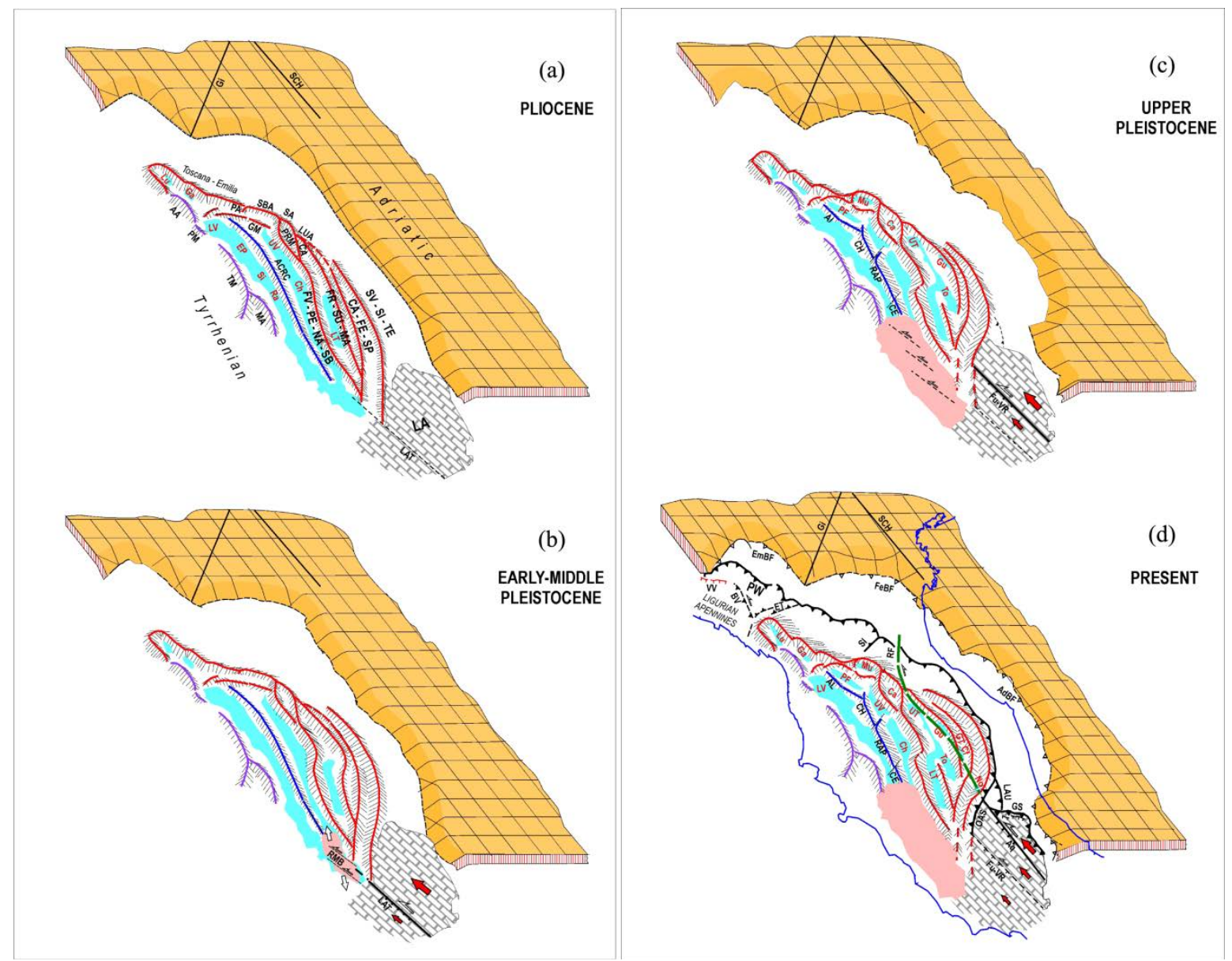

Figure 5. Tentative reconstruction of the main morphological elements (ridges and basins) in the Northern Apennines since the Pliocene. a) Pliocene. The red lines identify the main ridges in the RMU and TE wedges: CA = Catenaia Alps, CA-FE$\mathrm{SP}=$ Catria-Fema-Spoleto, FR-SU-MA = Frontano-Subasio-Martani, FV-PE-NA-SB = Favalto-Peglia-Narni-Sabini, GM = Giovi-Morello, LUA = Luna Alps, PA = Pistoia Apennines, PRM = Pratomagno, SA = Serra Alps, SBA = San Benedetto Alps, SV-SI-TE = S.Vicino-Sibillini-Terminillo. The blue line indicates the Albano-Chianti-Rapolano-Cetona (ACRC) ridge. The violet lines indicate the metamorphic ridge (taken as the inner limit of our reconstruction): AA = Apuane Alps, MA = Montalcino-Amiata, PM = Pisano Mt., TM = Toscana metamorphic belt. The blue zones identify the main basins: Ch = Chiana, $\mathrm{EP}=$ Elsa-Pesa, $\mathrm{Ga}=$ Garfagnana, $\mathrm{LT}=$ Lower Tiber, $\mathrm{Lu}=$ Lunigiana, $\mathrm{LV}=$ Lower Valdarno, $\mathrm{Ra}=\mathrm{Radicofani}, \mathrm{Si}=$ Siena, UV = Upper Valdarno. LA = Lazio-Abruzzi platform, LAT = Latina fault system; b) Early-Middle Pleistocene. RMB $=$ Roman Magmatic Body; c) Upper Pleistocene. New basins: $\mathrm{Ca}=$ Casentino, $\mathrm{Gu}=$ Gubbio, $\mathrm{Mu}=\mathrm{Mugello}, \mathrm{PF}=\mathrm{Pis}-$ toia-Firenze, To $=$ Topino, UT $=$ Upper Tiber. Segments of the previous ACRC ridge: $\mathrm{AL}=\mathrm{Albano}, \mathrm{CE}=\mathrm{Cetona}, \mathrm{CH}=$ Chianti, RAP = Rapolano. Fu-VR = Fucino-Val Roveto fault system; d) Present. Aq = L'Aquila fault system, GS = Gran Sasso arc, LAU = Laga units. Other symbols and abbreviations as in Figure 2. See text for explanations. 
[44], so the push of the Southern Apennines was transmitted by a large part of LA. At that time, the Northern Apennines were mainly constituted by a system of almost parallel ridges and basins, formed in the late Miocene and early-middle Pliocene tectonic phases [4] [8] [45]-[47].

In the early Pleistocene (Figure 5(b)), the activation of the Latina fault system allowed the eastern LA sector to decouple from its inner part and accelerate roughly NNW ward, under the drag of Adria. Since then, the indentation of such LA wedge caused outward escape and oroclinal bending of the main ridges in the Northern Apennines. This effect was particularly intense in the zones lying just north of the LA indenter (i.e. Olevano-Antrodoco, Sabini Mts. and Narni). The oblique divergence between the outward escaping wedges and the inner more stable structures induced transtensional deformation in the zone that now is covered by the Roman magmatic products [48]. The plausibility of this hypothesis is supported by the fact that such kind of strain regime, often accompanied by the generation of pull-apart troughs, can produce sub-vertical fractures in the upper crust, that represent preferential pathways for melt ascent [49]-[52].

In the upper Pleistocene (Figure 5(c)), belt-parallel decoupling inside the LA platform became more and more efficient in the Val Roveto and Fucino fault systems, while the Latina fault system was affected by less and less activity. The new configuration of the LA indenter caused stronger and stronger bending and outward escape of orogenic material in the outer part of the RMU units, also reaching the northern ridges (LUA, SBA, PRM, CA). In some zones, the divergence between adjacent ridges which were undergoing different lateral bending, caused the generation of transtensional troughs. Such mechanism may have formed the Casentino and Upper Tiber troughs, as effect of oroclinal bending in the Romagna-Umbria Apennines. Similarly, oroclinal bending in the Toscana Apennines (Figure 5(c)) may have formed the Firenze-Pistoia and Mugello troughs and accelerated the development of the Lunigiana and Garfagnana basins. The fact that oroclinal bending has not affected the westernmost edge of the belt (Ligurian Apennines), can be explained by the absence of late Triassic evaporites (Burano Formation) at the base of that sector [18]-[20].

It is worth noting that all major ridges involved in the proposed deformation pattern have undergone a complete erosion of the Ligurian units that were previously located at the top of the Apennine thrust stack [53]. Indeed, such stack has been preserved only in the sectors not involved in oroclinal bending, such as the Ligurian and Emilian Apennines [54] [55]. This evidence, often interpreted as an effect of significant uplift [56]-[58], is consistent with the proposed interpretation since the lateral bending of orographic sectors is mostly accompanied by significant uplift. The peculiar presence of Ligurian units on top of the Mt. Morello-Mt. Giovi ridge may be due to the fact that such sector, being located in the inner part of an orocline (formed by Pratomagno, S. Benedetto Alps ridges), did not underwent significant uplift and consequent erosion.

The scheme of Figure 5 also suggests that since the upper Pleistocene the Albano-Chianti-Rapolano-Cetona ridge, has undergone significant belt-parallel shortening, which was mostly accommodated by uplift and some lateral shifts (Figure 5(c)). In particular, the sinistral lateral displacement and uplift of the Rapolano ridge along the Ambra fault system (shown in Figure 7), may have generated the relief now located between the Upper Valdarno and Chiana basins. The compressional interaction between the Chianti ridge and the Northern RMU wedge may have enhanced the relief that now separates the Pistoia-Firenze basin from the Upper Valdarno basin. The evidence and arguments that support the above interpretation are described in the next section.

During the last evolutionary phase (Figure 5(d)), the Gran Sasso Arc started developing as effect of the beltparallel push of the northeastern sector of the Molise-Sannio wedge. In the inner side of the Gran Sasso Arc (experiencing a transtensional regime), the L'Aquila fault system developed.

Since the late Pleistocene (Figure 5(d)), decoupling in the LA platform has continued to develop at the Fucino fault, but the most efficient and frequent seismic decoupling has involved the L'Aquila fault system. This decoupling and the consequent acceleration of the Gran Sasso wedge, has induced shear stress in the RMU units, causing the formation of a major fault system (Norcia-Colfiorito-Gualdo Tadino-Gubbio), which has been the source of major earthquakes (e.g., Figure 3(c) and Figure 3(d)). Sometimes, this decoupling extends northward, through the Upper Tiber and Romagna-Forli fault systems [4] [5] [43], which allow the complete decoupling of the ORMU wedge from the IRMU wedge.

The roughly belt-parallel compression exerted by the RMU wedge causes shortening in the Padanian side of the Toscana-Emilia Apennines. One possible effect of this process is recognized in the Sillaro front (Figure 5(d)), where the Umbria-Marche turbiditic units, outcropping in the Romagna Apennines, underthrust the Emilia Apennines, still covered by the Ligurian units [58].

Another major consequence of belt-parallel shortening in the Emilian Apennines may be the roughly NNW 
ward lateral escape of the Piacenza wedge (Figure 5(d)). The decoupling between this wedge and the Ligurian Apennines is accommodated by sinistral transpressional motion at the Bedonia-Varzi fault system and by roughly N-S divergent motion at the Villarvernia-Varzi (VV) fault, both characterized by significant seismic activity (e.g., [59]-[62]. The kinematics proposed for the Piacenza wedge is compatible with the configuration of the Emilia folds [63]-[65], presumably formed by the roughly northward displacement of this indenter. The decoupling of the Piacenza wedge from the eastern portion of the Emilia Apennines could be accommodated by transpressional deformation at the Enza-Taro fault system, evidenced by various tectonic features [62] [66]-[68]. It is worth noting that the Enza-Taro fault may be the surface projection of a discontinuity (Giudicarie) that affects the Adria domain [39] [69]. Some possible connections between the tectonic implications of the above mentioned context and the spatio-temporal distribution of major earthquakes are discussed by [70].

\section{Seismotectonic Setting in the Inner Side of the Northern Apennines}

This zone is characterized by a rough morphology, where mountain ridges alternate with flat or undulated plains, drained by fluvial systems flowing towards the Tyrrhenian Sea (Figure 6). The tectonic units generated by deformation of the Ligurian and Toscana domains, along with metamorphic complexes derived by the same domains and by the crustal basement, outcrop at ridges, such as the Colline Metallifere, Toscana Metamorphic, Montalcino-Amiata, Albano, Chianti, Rapolano and Cetona ones. On the other hand, the plains are marine and continental basins formed since the late Miocene [47] [71].

The oldest (late Miocene-lower Pliocene) marine basins (e.g., Tora-Fine, Era, Radicondoli, Elsa-Pesa, Siena and Radicofani) are located west of the Albano, Chianti, Rapolano and Cetona ridges. Younger (late Pliocene-

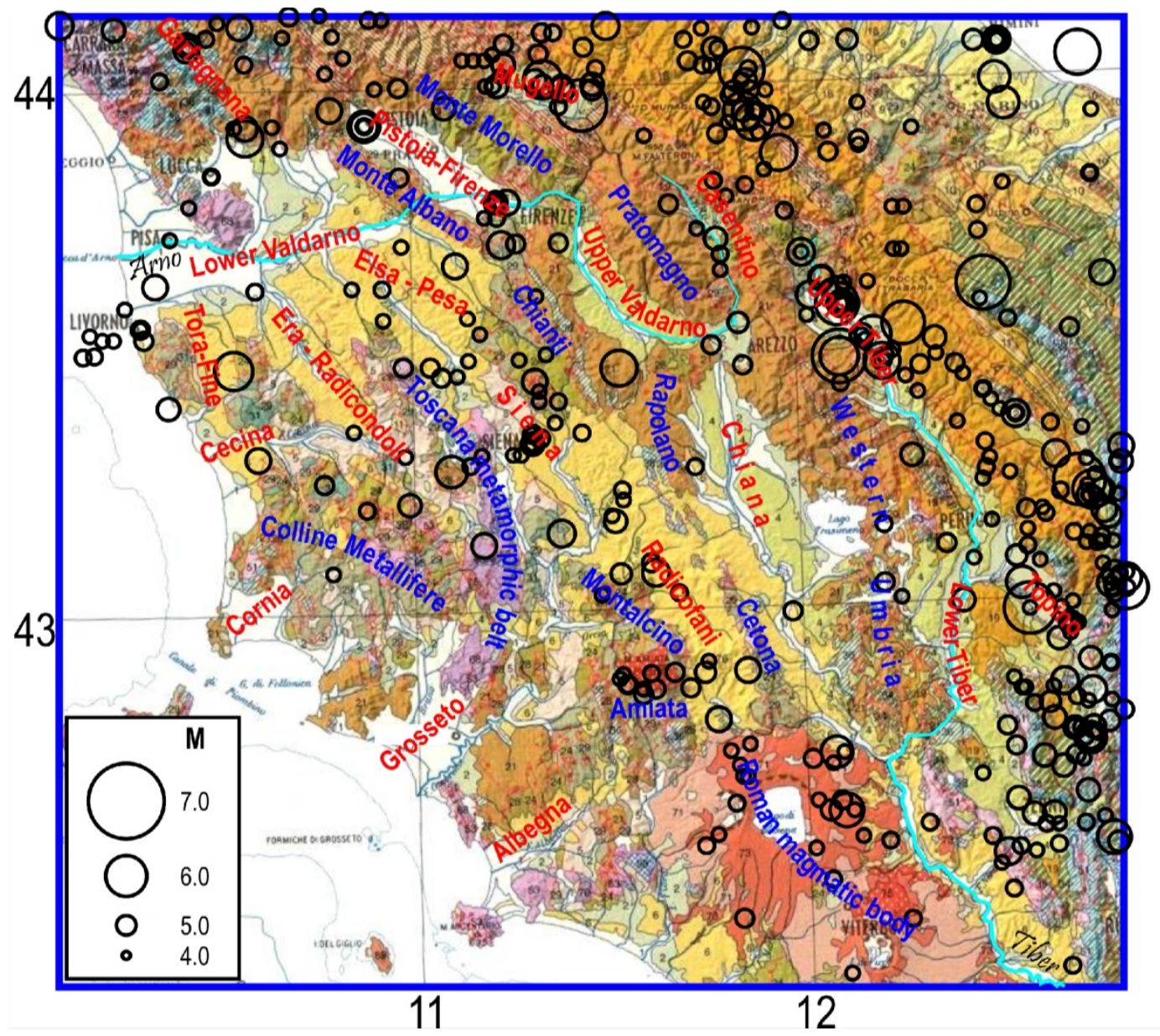

Figure 6. Main basins and ridges in the inner part of the Northern Apennines (central-western Toscana), reported on the Geological Map of Italy [74]. Circles indicate seismic activity (from [1]). 
Pleistocene) fluvio-lacustrine basins (Upper Valdarno and Chiana) lie between the above ridges and the reliefs of Pratomagno and Western Umbria. East of such reliefs, there are the most recent intramontane basins (Pistoia-Firenze, Mugello, Casentino, Upper Tiber).

The conventional description of the post-Tortonian tectonic development of the Northern Apennines [47] [72] provides that after the late Oligocene-Miocene main compressional phases, an almost pure extensional tectonic regime has affected the inner side of the belt since the late Miocene. In this view, the above-mentioned basins are described as grabens or semi-grabens, bounded by NW-SE trending, high-angle normal faults and separated each other by horsts, often corresponding to the outcrop of pre-late Miocene rocks.

The longitudinal continuity of the basins is often interrupted by NE-SW trending old transversal lineaments which have considerably influenced the deposition processes [73].

However, in the last decades this interpretation has been revised or confuted at all. Detailed accounts of the related debate can be found in [75] [76]. Here, we point out some issues about the Quaternary evolution of the study area that do not fit well the above interpretation.

1) Significant deposition has occurred or continued through the Quaternary in some basins located near the Tyrrhenian coast (e.g., Lower Valdarno and Grosseto [77]). On the other hand, sedimentation has been interrupted since the middle-late Pliocene in eastern basins (Elsa-Pesa, Era-Radicondoli and Siena-Radicofani [78] [79]).

2) Some basins are elongated roughly E-W (Lower Valdarno and Cecina) or NE-SW (Cornia, Grosseto, Albegna), rather than NW-SE.

3) The presence, geometry, kinematics and timing of the normal faults bounding the above mentioned basins are debated [75] [76] [80]. For instance, [81] suggest that the SW-dipping Cetona fault (Figure 7) has been inactive since the early Quaternary. However, [82] recognize for that fracture significant late Quaternary-Present activity, which has produced a considerable dip-slip offset (about $85 \mathrm{~m}$ ).

4) In several sectors of this zone, significant uplift has affected both basins and ridges during the Quaternary [46] [78] [83]-[85], a scenario that can hardly be reconciled with a purely extensional regime.

Considering these (and others) major problems, we think that looking for a more satisfactory explanation of the observed deformation pattern is opportune. To this regard, it is argued that the late Quaternary tectonic activity in the study area has been driven by belt-parallel compression, induced by the push of the inner sectors of the Southern and Central Apennines (Figure 2).

The effects of the proposed kinematic/dynamic context have probably been emphasized by the peculiar mechanical properties of the crust in the Roman magmatic body, that, being pervaded by magmatic intrusions [86], is presumably characterized by higher rigidity with respect to the surrounding orogenic structures and can thus more efficiently transmit the roughly northward push of the Central and Southern Apennines [4] [8].

The compatibility between the implications of the proposed driving mechanism and the major Quaternary deformation observed in the study area (Figure 7), are discussed in the following.

The hypothesis that the Albano-Chianti-Rapolano-Cetona ridge has undergone longitudinal shortening (Figure 5), accommodated by uplift and lateral shifts, is consistent with the following observed features:

1) Uplifted Pleistocene deposits have been recognized in the segments of the above ridge and in the adjacent basins, such as the Elsa-Pesa, Siena, Radicofani and Upper Valdarno [78] [46] [83]-[85] [88]-[90]. This phenomenon has also been recognized in the easternmost margin of the Firenze basin [84] [91]-[95].

2) During the late Pleistocene, the Arno river has undergone a drastic deviation, turning from a roughly southward path to the present one [91] [92] [96] [97]. This event could be an effect of the dextral displacement and uplift that the Rapolano ridge (Figure 7) has undergone to accommodate the supposed longitudinal shortening. This hypothesis is compatible with the focal mechanism (sinistral strike-slip) recognized for the 1558 earthquake ( $M=5.8)$ that activated the sinistral Rapale fault in the Val D'Ambra [98].

3) The Cetona and Rapolano ridges are dissected by SW-NE sinistral transversal fault systems, such as the Sentino and Sarteano ones (Figure 7), where pull-apart mechanisms are recognized [81] [99] [100].

4) Some Quaternary NE-SW trending sinistral transtensional fault systems are recognized in the basins located along the inner side of the Albano-Chianti, Rapolano and Cetona ridges, i.e. the Elsa-Pesa and Siena-Radicofani. The Poggibonsi lineament separates the Elsa-Pesa from the Siena basin [101]. More to the south, the sinistral Arbia fault could represent the westward prosecution, through the Siena Basin, of the Ambra fault [102].

5) The longitudinal compression exerted by the Rapolano ridge, being mostly applied to the eastern sector of 


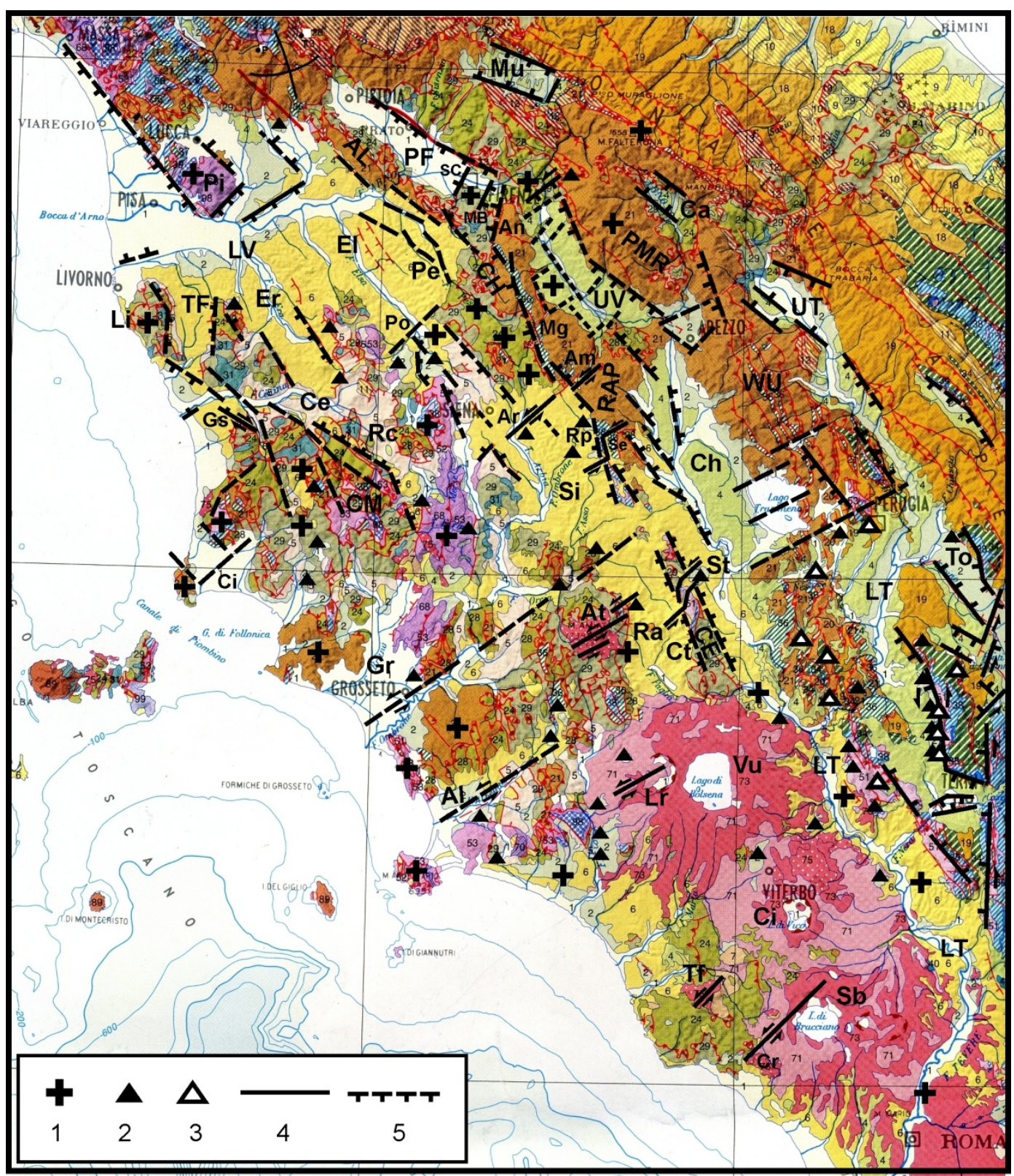

Figure 7. Main tectonic features recognized in the study area, reported onto the Geological Map of Italy [74]. 1) Quaternary uplift 2) Deposits of travertines and calcareous tufa [87] 3) Quaternary Umbrian volcanism [48] 4) Faults where late Quaternary activity is likely 5) Inferred or buried faults with uncertain late Quaternary activity. Northern Lazio volcanoes (Roman magmatic body): $\mathrm{Ci}=$ Cimini, $\mathrm{Sb}=$ Sabatini, $\mathrm{Vu}=$ Vulsini. Main ridges: $\mathrm{AL}=\mathrm{Albano}, \mathrm{CE}=\mathrm{Cetona}, \mathrm{CH}=\mathrm{Chianti}, \mathrm{CM}=$ Colline Metallifere, $\mathrm{Li}=$ Livorno Mts., Pi $=$ Pisano Mt., PRM = Pratomagno, RAP = Rapolano, WU = Western Umbria. Neogene basins: $\mathrm{Al}=$ Albegna, $\mathrm{Ca}=$ Casentino, $\mathrm{Ce}=\mathrm{Cecina}, \mathrm{Ci}=\mathrm{Cornia}, \mathrm{Ch}=$ Chiana, $\mathrm{El}=\mathrm{Elsa}, \mathrm{Er}=\mathrm{Era}, \mathrm{Gr}=\mathrm{Grosseto}$, $\mathrm{LT}=$ Lower Tiber, $\mathrm{LV}=$ Lower Valdarno, $\mathrm{Mu}=$ Mugello, $\mathrm{Pe}=$ Pesa, $\mathrm{PF}=$ Pistoia-Firenze, $\mathrm{Rc}=$ Radicondoli; $\mathrm{Ra}=$ Radicofani, $\mathrm{Si}=$ Siena, $\mathrm{TF}=$ Tora-Fine, To $=$ Topino, UV $=$ Upper Valdarno, UT $=$ Upper Tiber. Fault systems: An $=$ Antella, $\mathrm{Am}=$ Ambra (Rapale), $\mathrm{Ar}=$ Arbia, $\mathrm{At}=$ Amiata, $\mathrm{Cr}=$ Ceriti, $\mathrm{Ct}=$ Cetona, $\mathrm{Gs}=$ Guardistallo, $\mathrm{Lr}=\mathrm{Latera}, \mathrm{MB}=$ Maiano-Bagno a Ripoli, $\mathrm{Mg}=$ Montegrossi, $\mathrm{Po}=$ Poggibonsi, $\mathrm{Rp}=$ Rapolano, $\mathrm{Sc}=$ Scandicci-Castello, $\mathrm{Se}=\mathrm{Sentino}, \mathrm{St}=$ Sarteano, $\mathrm{Tf}=$ Tolfa. The map is based on the information provided by the sources cited in the text.

the Chianti ridge could be responsible for the generation of a longitudinal decoupling faults located inside that ridge, such as the SSE-NNW Montegrossi fault system (Figure 7 [103]). The above fault may allow a sinistral sliding between the eastern and western parts of the Chianti ridge. 
6) More to the North, the relative northward displacement of the Chianti ridge with respect to the adjacent less mobile structures (Albano ridge and Firenze-Pistoia basin) may be accommodated by a system of S-N to SWNE faults, such as the Antella, Maiano-Bagno a Ripoli and Scandicci-Castello ones [84] [93] [94] [104] [105], which are probably related with the most intense historical earthquakes (1148 I $=$ VII, M $=5.2 ; 1453 \mathrm{I}=$ VIIVIII, $\mathrm{M}=5.3 ; 1895 \mathrm{I}=$ VIII, $\mathrm{M}=5.4 ; 1959 \mathrm{I}=\mathrm{VII}, \mathrm{M}=4.8$ ) that occurred in the Firenze area (Figure 8).

7) The recent seismic swarms occurred in the Elsa-Pesa and western Chianti zones (from December, 2014 until January, 2015) may have been generated by the system of SSE-NNW to S-N faults in the Elsa-Pesa basin, which might constitute the northward prolongation of the faults located in the western side of the Chianti ridge (Figure 7). This hypothesis is compatible with the fault plane solutions of six moderate shallow earthquakes occurred during the above swarms, which coherently indicate a strike-slip strain regime, with $\mathrm{P}$ and $\mathrm{T}$ axes directed NW-SE and NE-SW respectively (data available at $\underline{h t t p: / / c n t . r m . i n g v . i t / t d m t . h t m l) . ~ T h e s e ~ f a u l t s ~ a r e ~ p r o b a-~}$ bly related with the 1812 intense earthquake ( $\mathrm{I}=\mathrm{VII}-\mathrm{VIII}, \mathrm{M}=5.2)$.

The proposed tectonic setting in the interaction zone between the Chianti ridge and the RMU wedge implies that the fault systems located in the Firenze area and the ones lying in the western Chianti and Elsa-Pesa zones

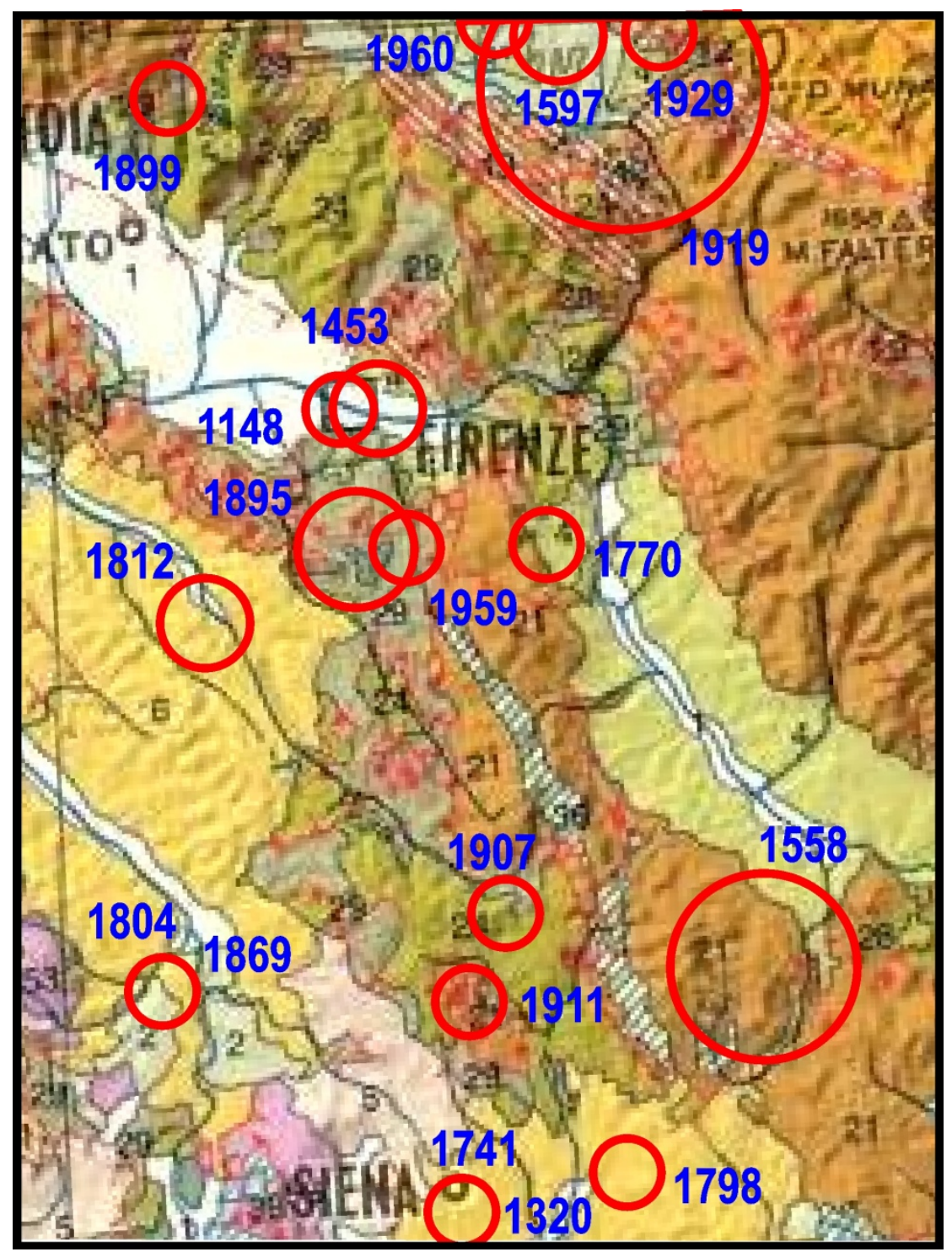

Figure 8. Main historical earthquakes with MCS Intensity $\geq$ VII, occurred in the Firenze area and surroundings (data from [1]). 
both favour the decoupling of the Chianti ridge from the less mobile structures (Albano ridge and Pistoia-Firenze basin) lying to the west of that ridge. This means that the seismic activation of one of those fault systems may increase tectonic load (and earthquake probability) in the other zone. Such tectonic connection could explain why the seismic phases in those two zones show an interesting time correlation (Figure 9). This correspondence holds in particular for the seismic period that roughly started in 1887 in the Firenze zone, but also involves other shorter phases in those zones.

The fact that the Upper Valdarno and Chiana basins are almost aseismic, while seismic activity in the inner belt mainly occurs within a relatively S-N narrow zone, corresponding to the Elsa-Pesa-Siena-Radicofani basins (Figure 6), might imply that the oroclinal bending of the Chianti-Rapolano-Cetona ridge tends to create a compressional regime at its outer margin (upper Valdarno and Chiana basins) and an extensional/transtensional regime at its inner boundary (Elsa-Pesa-Siena-Radicofani basins).

Some pieces of evidence compatible with belt-parallel compression are also recognized in the western part of Toscana and northern Lazio:

-Late Quaternary uplift is recognized in the Lower Tiber valley [108] [109], the Toscana Metamorphic belt [77] [110], the Tyrrhenian coast of Lazio [111] [112] and the coastal relief of western Toscana [77] [111] [113]. Locally, uplift may have been emphasized by the emplacement of magmatic bodies [83] [114] [115].

-Between the Colline Metallifere and the Livorno Mts, a fault system formed by WNW-ESE to N-S trending lineaments has been recognized [116]. The most recent activity of such faults is compatible with strike-slip kinematics [117]. For instance, the WNW-ESE Guardistallo fault (Figure 6) behaved as a dextral transtensional feature in the late Quaternary [118].

-The NE-SW Amiata fault system has probably controlled the emplacement of late Pleistocene volcanic products [119]-[121]. The recent (late Quaternary) activity of such transtensional fault systems is suggested by the continuous deposition of travertines and calcareous tufa [87] [119]. The orientation of the fault systems so identified is compatible with the belt-parallel stress regime implied by our interpretation.

-Some authors [62] [122] recognize in southwestern Toscana zone NE-SW tectonic lineaments, such as the
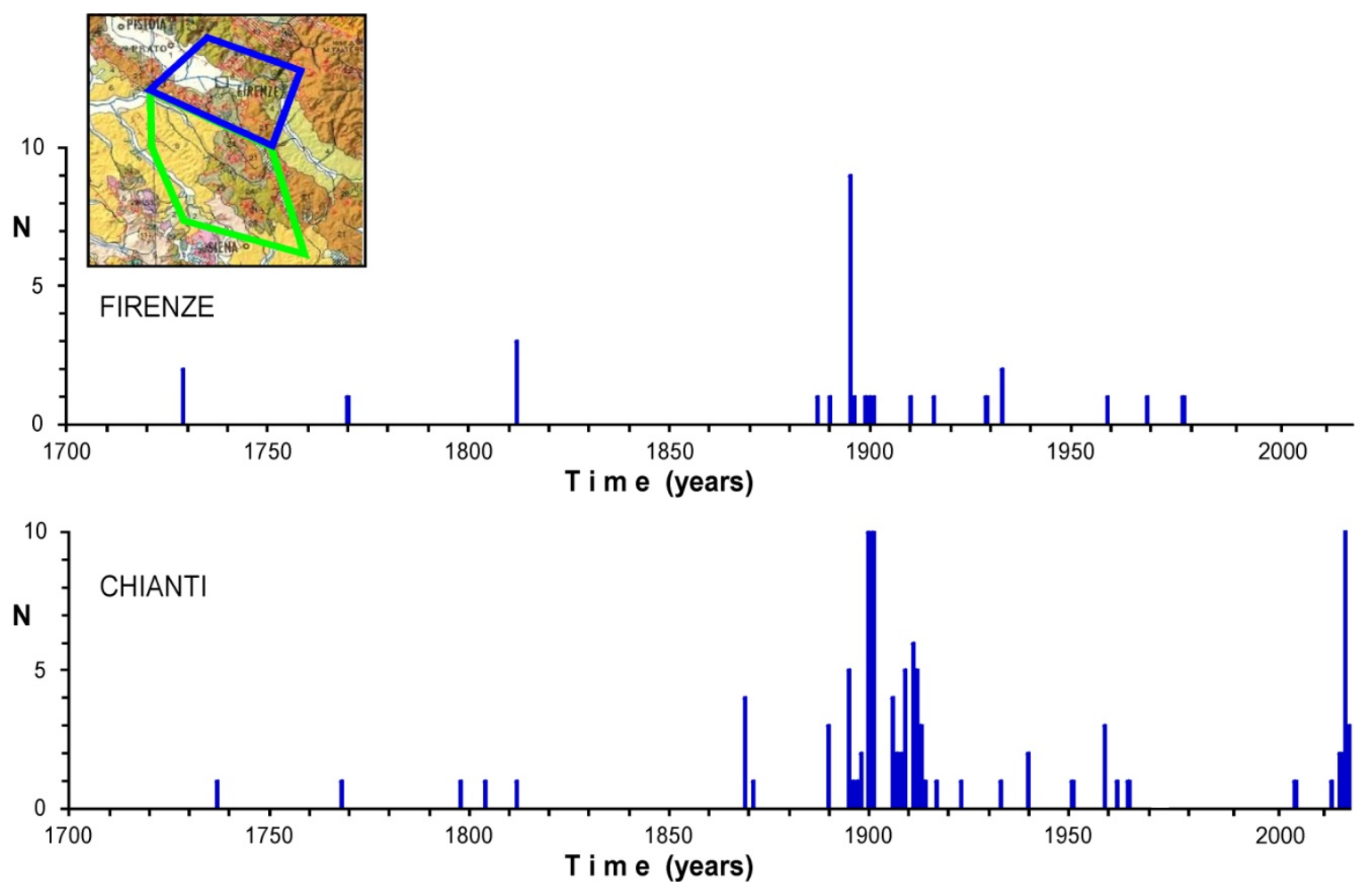

Figure 9. Time patterns of seismic activity $(\mathrm{N}=$ number of events with $\mathrm{M}>3)$ in the Firenze (blue contour in the map) and Western Chianti-Elsa Pesa (green contour) zones [106] [107]. 
Grosseto and Albegna ones, that interrupt the continuity of the pre-Neogene ridges. Significant travertine deposition, indicating Quaternary activity, has been recognized near those lineaments [87] [123].

-In the Roman magmatic province, the role of NE-SW trending sinistral faults (Ceriti, Latera and Tolfa in Figure 7) has been pointed out by [52].

-Seismic activity in the western Toscana (Figure 1 and Figure 6) is not negligible, although relatively infrequent. Major earthquakes (magnitude $\mathrm{M} \geq 5.5$ ) hit the Colline Metallifere (1414) and Tora-Fine basin (1846); several shocks with $4 \leq \mathrm{M}<5.5$ are documented since $1000 \mathrm{AD}$ [1].

\section{Present Kinematic Pattern in the Apennine Belt by GPS Data}

The GPS observations obtained from several continuous operating networks in the study area have been considered in order to recognize the present horizontal kinematic field in the Central and Northern Apennines [10]. In particular, the phase and pseudo-code data of 450 continuous stations operating over the period January 1, 2001December 31, 2014 have been analysed with the GAMIT software version 10.5 [124] adopting a distributed procedure [125]. The network has been divided into 30 sub-networks (clusters) following a simple geographic criterion, while maintaining the shortest baseline as possible. Loose constraints have been assigned to the daily position coordinates of each station belonging to all clusters. The International GPS service for Geodynamics (IGS) precise orbital solutions from Scripps Orbit and Permanent Array Center have been included in the processing with tight constraints, such as the Earth Orientation Parameter. The daily loosely constrained solutions have been combined into a unique solution by the GLOBK software [126], and aligned into the ITRF2008 reference frame [127] by a weighted six parameters transformation (three translations and three rotations), using the ITRF2008 coordinates and velocities of 15 high-quality common IGS stations [7] [128].

At the end of this procedure, the ITRF2008 time series of the north, east and vertical components of the geographical position of each site included in the analysis have been estimated. Then, these series have been analyzed following the procedure described by [10] [128], in order to estimate the absolute velocity values. Only the sites with a minimum observation period of 2.5 years have been included in the processing in order to avoid biases due to unreliable estimated seasonal signal [129] and underestimate of rate uncertainties, due to short time series [130]. The uncertainties associated to the velocity have been estimated adopting the Allan Variance of the Rate method introduced by [131] in order to take into account the correlated noise of the GPS daily position time series.

The resulting ITRF2008 velocity field with respect to an Eurasian frame [127] is mapped in Figure 10. This pattern confirms the major features of the kinematics tentatively deduced by Quaternary deformations (Figure 2), in particular the fact that the outer part of the Apennine belt moves faster and with a greater eastward component, with respect to the inner belt.

The relatively high density of GPS sites in the Central and Northern Apennines has allowed us to tentatively define the boundaries between roughly homogeneous kinematic domains (Figure 11).

The highest velocities ( $v \geq 3 \mathrm{~mm} / \mathrm{y})$, mainly oriented NE ward, are observed in the outer belt, including the Adriatic and Ferrara buried folds (Figure 2), that is delimited by the blue and green lines.

In the innermost sector, delimited by the violet line, the vectors are oriented from NW to North ward in the southern part and roughly NE ward in the northern part. The velocities are lower than $1.5 \mathrm{~mm} / \mathrm{y}$. This kinematic domain mostly corresponds to the grey area in Figure 2.

The intermediate domain, comprised between the violet and green lines in Figure 11, is characterized by lower velocities $(2 \leq \mathrm{v}<3 \mathrm{~mm} / \mathrm{y})$ with respect to the outer belt, with prevailing $\mathrm{S}-\mathrm{N}$ orientations in the southern portion and roughly SW-NE orientation in the northern portion. This domain roughly corresponds to the IRMU wedge in Figure 2.

In the Central Apennines, the transition from high to low velocities is rather sharp, mainly corresponding to the Fucino-Val Roveto fault system.

It would be useful to gain insights into how the present kinematics may be influenced by the post seismic relaxation induced by the major earthquakes recently occurred in the study area [35] [36]. To this purpose, we have taken into account the seismicity that has occurred in the Apennine belt since 1930 (Figure 12), i.e. in the period that has followed the last migrating seismic sequence shown in Figure 3(d). The seismicity pattern in this last period (Figure 12) shows a progressive northward migration of major shocks along the Apennine belt, 


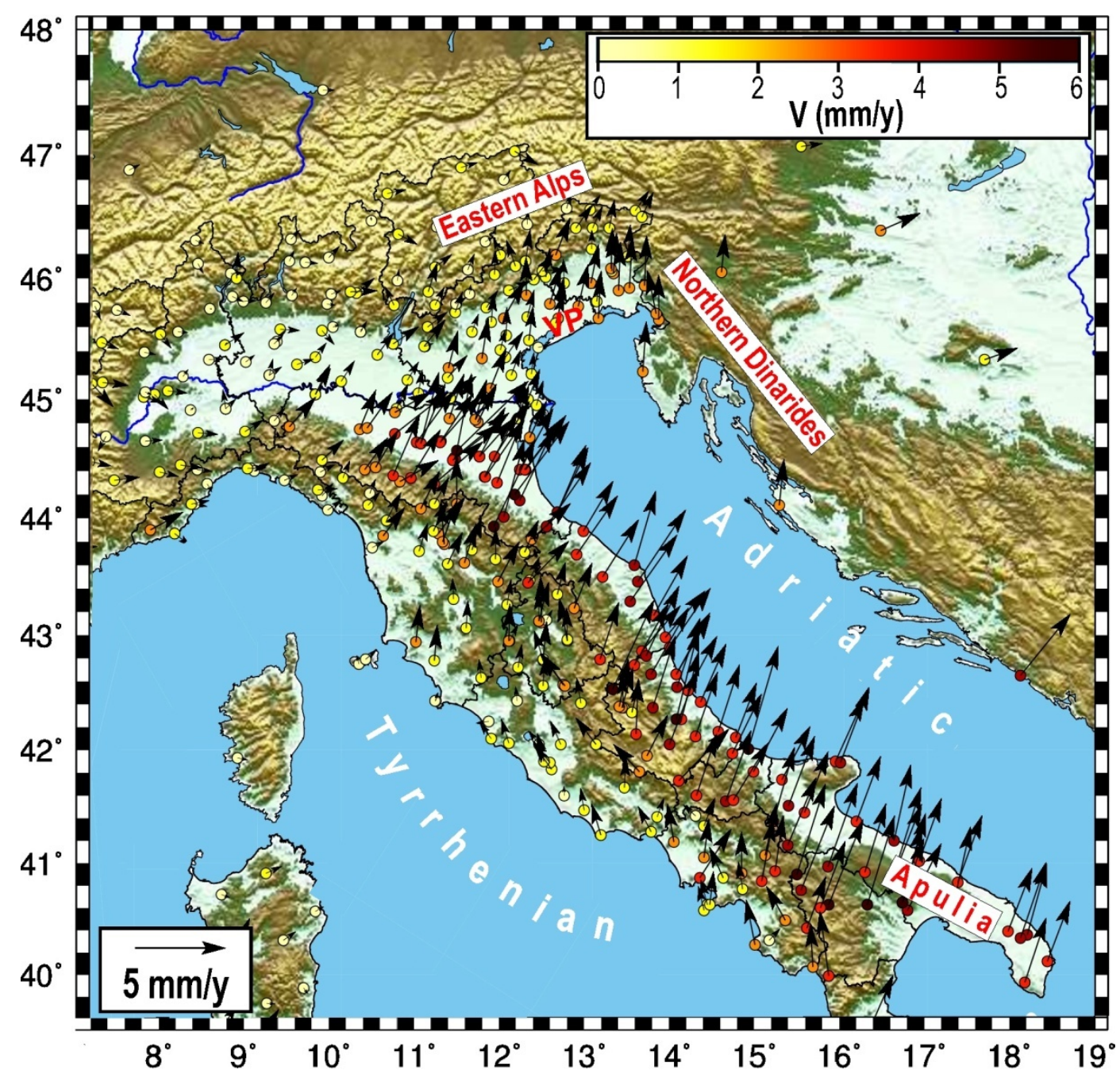

Figure 10. Horizontal velocities (black vectors) of the considered GPS sites with respect to a fixed Eurasian frame (Euler pole at $54.23^{\circ} \mathrm{N}, 98.83^{\circ} \mathrm{W}, \omega=0.257^{\circ} / \mathrm{Myr}$ [127]. The colours of the circles indicate the velocity, following the chromatic scale on the top of the figure. VP = Venetian Plain.

similarly to what happened in the previous major seismic sequences [6]. Above all, it is worth noting that in the period considered seismic activity has mainly affected the Southern and Central Apennines, the Southern Dinarides and Albania, whereas only few shocks have occurred in the Northern Apennines, Eastern Alps and Northern Dinarides. Considering the post-seismic relaxation that has been triggered by this non homogeneous distribution of periAdriatic seismic decouplings, one may suppose that the present motion rate of the southern Adria domain is higher than the one of northern Adria. This hypothesis is consistent with the GPS velocity field (Figure 10), which shows velocities of about $4-5 \mathrm{~mm} / \mathrm{y}$ in southern Adria (Apulia zone) and rates lower than 3 $\mathrm{mm} / \mathrm{y}$ in the northern Adria domain (Venetian Plain). This presumed short-term kinematic pattern would imply the occurrence of transient internal deformation in the Adria promontory, accommodated for instance by upward flexure. These remarks, even though hypothetical, may discourage the use of GPS data for determining the rotation pole of a rigid Adria plate or recognizing the presence of Adriatic microplates. As concerns seismic hazard, the present stage of the ongoing peri Adriatic seismic sequence (Figure 12) could imply that the probability of seismic activation at the bounda ries of northern Adria (Northern Apennines, Northern Dinarides and Eastern Southern Alps) is higher than the one of seismic activations at the boundaries of southern Adria.

Some considerations about seismic hazard can also be made for the Northern Apennines. In this zone, the proposed tectonic context suggests that after the activation of the Norcia-Colfiorito-Gualdo Tadino-Gubbio faultsystem (1979, 1984 and 1997), the northern portion of the RMU wedge has undergone a significant accelera- 


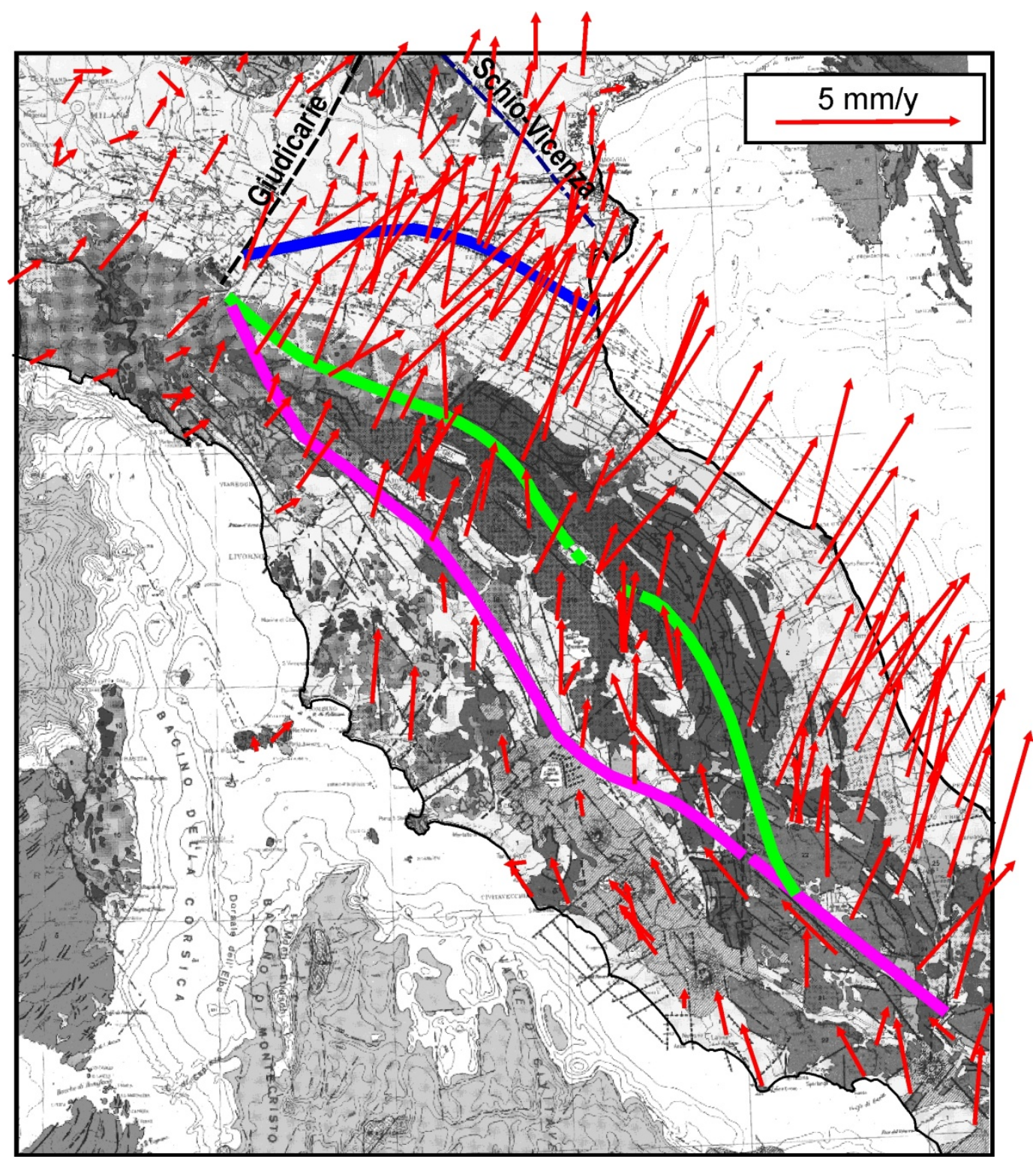

Figure 11. Tentative recognition of the boundaries (violet, green and blue lines) between roughly homogeneous kinematic domains (GPS) in the Central and Northern Apennines. See text for comments.

tion, enhancing stress at its main boundaries (Upper Tiber trough, Sillaro thrust front, Pistoia Apennines and Ferrara buried folds in Figure 2) and at the major decoupling fault lying inside the RMU wedge (Romagna-Forli). This hypothesis, reinforced by the post seismic relaxation triggered by the 2009 L'Aquila shock $(M=6.3)$, is consistent with the occurrence of the 2012 earthquakes in the Ferrara buried folds $(M=5.8,5.9)$.

\section{Conclusions}

It is argued that the complex tectonic pattern presently recognized in the Northern Apennines has mainly been determined by belt-parallel shortening and by the fact that such process has developed at higher rates in the outer sector of the belt (RMU and TE wedges). Most major seismic sources (Norcia-Colfiorito-Gualdo Tadi-no-Gubbio-Upper Tiber, Mugello, Garfagnana and Lunigiana) are located in the zones where adjacent ridges have undergone different oroclinal bendings, inducing transtensional deformation. The fact that the effects of the above shortening processes have progressively involved more and more outer sectors of the Northern Apen- 




Figure 12. Distribution of major earthquakes that have occurred in the peri Adriatic regions since 1930 (data from [5] and references therein).

nines is closely connected with the activation of more and more eastern decoupling fault systems (Latina, Val Roveto, Fucino and L'Aquila) in the Lazio-Abruzzi indenter (Figure 5).

The recent (late Pleistocene) development of the L'Aquila fault, in the inner side of the Gran Sasso arc, has favoured the formation of a major discontinuity in the Northern Apennines (Norcia-Colfiorito-Gualdo TadinoGubbio), whose seismic activations allow the transtensional decoupling of the outermost sector of the RMU wedge from the inner belt (Figure 2 and Figure 5(d)). Sometimes, this decoupling extends northward, through the Upper Tiber and Romagna-Forlì fault systems.

The location, geometry and timing of magmatic activity in the Roman province (Figure 5) are compatible with the expected evolution of the transtensional stretching that has developed between the NE ward escaping wedges (stressed by the LA indenter) and the inner more stable chain (Figure 5(b) and Figure 5(c)).

Belt-parallel compression has also stressed the inner side of the Northern Apennines, even though at a lower rate. Such process has caused longitudinal shortening and uplift of the ridge and basin systems that have formed during the upper Miocene and early Pliocene. The most evident effects of this deformation can be recognized in the Albano-Chianti-Rapolano-Cetona ridge and surrounding basins. The proposed tectonic context can explain why the Upper Valdarno and Chiana basins, lying along the outer boundary of that ridge, are almost aseismic, whereas the Elsa, Pesa, Siena and Radicofani basins, lying at the inner side of the same ridge, are affected by seismic activity, even if moderate.

The interaction between the Chianti-Rapolano-Cetona ridge and the northern part of the RMU wedge has generated seismogenetic fault systems in the Firenze area. The correlation tentatively recognized between the time patterns of seismic activity in that zone and in the western Chianti area can be related with the fact that the activations of those fault systems favour the decoupling of the Chianti ridge from the surrounding structures.

The long-term kinematic pattern deduced by the Quaternary deformation is compatible with the present ve- 
locity field indicated by geodetic measurements. In particular, the above observations, being provided by a fairly dense network of continuous GPS sites, allow a good definition of the Apennine sectors which are characterized by different kinematic regimes.

\section{Acknowledgements}

We thank an anonymous Reviewer for his constructive and fruitful remarks.

\section{References}

[1] Rovida, A., Camassi, R., Gasperini, P. and Stucchi M., Eds. (2011) CPTI11, the 2011 Version of the Parametric Catalogue of Italian Earthquakes. Milano, Bologna. http://emidius.mi.ingv.it/CPTI

[2] Mazzoli, S., Pierantoni, P.P., Borraccini, F., Paltrinieri, W. and Deiana, G. (2005) Geometry, Segmentation Pattern and Displacement Variations along a Major Apennine Thrust Zone, Central Italy. Journal of Structural Geology, 27, 19401953. http://dx.doi.org/10.1016/j.jsg.2005.06.002

[3] Mantovani, E., Viti, M., Babbucci, D., Tamburelli, C. and Albarello, D. (2006) Geodynamic Connection between the Indentation of Arabia and the Neogene Tectonic Evolution of the Central-Eastern Mediterranean Region. In: Dilek, Y. and Pavlides, S. (Eds.), Postcollisional Tectonics and Magmatism in the Mediterranean Region and Asia, Geological Society of America Special Papers, Vol. 409, 15-41.

[4] Mantovani, E., Babbucci, D., Tamburelli, C. and Viti M. (2009) A Review on the Driving Mechanism of the Tyrrhenian-Apennines System: Implications for the Present Seismotectonic Setting in the Central-Northern Apennines. Tectonophysics, 476, 22-40. http://dx.doi.org/10.1016/j.tecto.2008.10.032

[5] Mantovani, E., Viti, M., Babbucci, D., Tamburelli, C., Cenni, N., Baglione, M. and D’Intinosante, V. (2015) Recognition of Peri-Adriatic Seismic Zones Most Prone to Next Major Earthquakes: Insights from a Deterministic Approach. In: D’Amico S. (Ed.), Earthquakes and Their Impact on Society, Springer Natural Hazard Series, Springer. (in press)

[6] Mantovani, E., Viti, M., Babbucci, D., Tamburelli, C., Cenni, N., Baglione, M. and D'Intinosante, V. (2015) Present Tectonic Setting and Spatio-Temporal Distribution of Seismicity in the Apennine Belt. International Journal of Geosciences, 6, 429-454. http://dx.doi.org/10.4236/ijg.2015.64034

[7] Mantovani, E., Viti, M., Cenni, N., Babbucci, D., Tamburelli, C., Baglione, M. and D’Intinosante, V. (2015) Seismotectonics and Present Seismic Hazard in the Tuscany-Romagna-Marche-Umbria Apennines (Italy). Journal of Geodynamics, 89, 1-14. http://dx.doi.org/10.1016/j.jog.2015.05.001

[8] Viti, M., Mantovani, E., Babbucci, D. and Tamburelli, C. (2006) Quaternary Geodynamics and Deformation Pattern in the Southern Apennines: Implications for Seismic Activity. Bollettino della Società Geologica Italiana, 125, $273-291$.

[9] Viti, M., Mantovani, E., Babbucci, D. and Tamburelli, C. (2011) Plate Kinematics and Geodynamics in the Central Mediterranean. Journal of Geodynamics, 51, 190-204. http://dx.doi.org/10.1016/j.jog.2010.02.006

[10] Cenni, N., Mantovani, E., Baldi, P. and Viti, M. (2012) Present Kinematics of Central and Northern Italy from Continuous GPS Measurements. Journal of Geodynamics, 58, 62-72. http://dx.doi.org/10.1016/j.jog.2012.02.004

[11] Finetti, I.R., Boccaletti, M., Bonini, M., Del Ben, A., Pipan, M., Prizzon, A. and Sani, F. (2005) Lithospheric TectonoStratigraphic Setting of the Ligurian Sea-Northern Apennines-Adriatic Foreland from Integrated CROP Seismic Data. In: Finetti, I.R., Ed., Deep Seismic Exploration of the Central Mediterranean and Italy, CROP Project, Chap. 8, Elsevier, Amsterdam, 119-158.

[12] Mirabella, F., Barchi, M., Lupattelli, A., Stucchi, E. and Ciaccio, M.G. (2008) Insights on the Seismogenic Layer Thickness from the Upper Crust Structure of the Umbria-Marche Apennines (Central Italy). Tectonics, 27, TC1010. http://dx.doi.org/10.1029/2007tc002134

[13] Anelli, L., Gorza, M., Pieri, M. and Riva, M. (1994) Subsurface Well Data in the Northern Apennines (Italy). Memorie della Società Geologica Italiana, 48, 461-471.

[14] Corrado, S., Di Bucci, D., Naso, G. and Faccenna, C. (1998) Influence of Palaeogeography on Thrust System Geometries: An Analogue Modelling Approach for the Abruzzi-Molise (Italy) Case History. Tectonophysics, 296, 437-453. http://dx.doi.org/10.1016/S0040-1951(98)00147-4

[15] Patacca, E., Scandone, P., Di Luzio, E., Cavinato, G.P. and Parotto, M. (2008) Structural Architecture of the Central Apennines: Interpretation of the CROP 11 Seismic Profile from the Adriatic Coast to the Orographic Divide. Tectonics, 27, TC3006. http://dx.doi.org/10.1029/2005tc001917

[16] Martinis, B. and Pieri, M. (1964) Alcune notizie sulla formazione evaporitica del Triassico Superiore nell'Italia centrale e meridionale. Memorie della Società Geologica Italiana, 4, 649-678.

[17] Zappaterra, E. (1990) Carbonate Paleogeographic Sequences of the Periadriatic Region. Bollettino della Società Geo- 
logica Italiana, 109, 5-20.

[18] Ciarapica, G. and Passeri, L. (2002) The Paleogeographic Duplicity of the Apennines. Bollettino della Società Geologica Italiana, 1, 67-75.

[19] Ciarapica, G. and Passeri, L. (2005) Late Triassic and Early Jurassic Sedimentary Evolution of the Northern Apennines: An Overview. Bollettino della Società Geologica Italiana, 124, 189-201.

[20] Bosellini, A. (2004) The Western Passive Margin of Adria and Its Carbonate Platforms. Special Volume of the Italian Geological Society for the 32nd International Geological Congress, Florence, 20-28 August 2004, 79-92.

[21] De Paola, N., Collettini, C., Faulkner, D.R. and Trippetta, F. (2008) Fault Zone Architecture and Deformation Processes within Evaporitic Rocks in the Upper Crust. Tectonics, 27, TC4017. http://dx.doi.org/10.1029/2007tc002230

[22] Funiciello, R., Parotto, M. and Praturlon, A. (1981) Carta Tettonica d'Italia, scala 1:1500000. CNR-PFG, Pubbl. No. 269, Grafica Editoriale Cartografica, Roma.

[23] Piccardi, L., Tondi, G. and Cello, G. (2006) Geo-Structural Evidence for Active Oblique Extension in South-Central Italy. In: Pinter, N., Grenerczy, G., Weber, J., Stein, S. and Medak, D., Eds., The Adria Microplate: GPS Geodesy, Tectonics and Hazard, NATO Science Series IV-Earth and Environmental Sciences, Springer, Berlin, Vol. 61, 95-108. http://dx.doi.org/10.1007/1-4020-4235-3_07

[24] Scisciani, V. and Calamita, F. (2009) Active Intraplate Deformation within Adria: Examples from the Adriatic Region. Tectonophysics, 476, 57-72. http://dx.doi.org/10.1016/j.tecto.2008.10.030

[25] Martelli, L., Camassi, R., Catanzariti, R., Fornaciari, E., Peruzza, L., Spadafora, E. and Rio, D. (2002) Note Illustrative della Carta Geologica d'Italia alla scala 1:50.000 foglio 265 Bagno di Romagna. SELCA, Florence, 1-108.

[26] Costa, M. (2003) The Buried, Apenninic Arcs of the Po Plain and Northern Adriatic Sea (Italy): A New Model. Bollettino della Società Geologica Italiana, 122, 3-23.

[27] Ascione, A., Cinque, A., Improta, L. and Villani, F. (2003) Late Quaternary Faulting within the Southern Apennines Seismic Belt: New Data from Mt. Marzano Area (Southern Italy). Quaternary International, 101-102, 27-41. http://dx.doi.org/10.1016/S1040-6182(02)00127-1

[28] Ascione, A., Caiazzo, C. and Cinque, A. (2007) Recent Faulting in Southern Apennines (Italy): Geomorphic Evidence, Spatial Distribution and Implications for Rates of Activity. Bollettino della Società Geologica Italiana (Italian Journal of Geosciences), 126, 293-305.

[29] Brozzetti, F. (2011) The Campania-Lucania Extensional Fault System, Southern Italy: A Suggestion for a Uniform Model of Active Extension in the Italian Apennines. Tectonics, 30, TC5009. http://dx.doi.org/10.1029/2010tc002794

[30] Cello, G., Mazzoli, S., Tondi, E. and Turco, E. (1997) Active Tectonics in the Central Apennines and Possible Implications for Seismic Hazard Analysis in Peninsular Italy. Tectonophysics, 272, 43-68. http://dx.doi.org/10.1016/S0040-1951(96)00275-2

[31] Piccardi, L., Gaudemer, Y., Tapponnier, P. and Boccaletti, M. (1999) Active Oblique Extension in the Central Apennines (Italy): Evidence from the Fucino Region. Geophysical Journal International, 139, 499-530. http://dx.doi.org/10.1046/j.1365-246x.1999.00955.x

[32] Tondi, E. and Cello, G. (2003) Spatiotemporal Evolution of the Central Apennines Fault System (Italy). Journal of Geodynamics, 36, 113-128. http://dx.doi.org/10.1016/S0264-3707(03)00043-7

[33] Viti, M., D’Onza, F., Mantovani, E., Albarello, D. and Cenni, N. (2003) Post-Seismic Relaxation and Earthquake Triggering in the Southern Adriatic Region. Geophysical Journal International, 153, 645-657. http://dx.doi.org/10.1046/j.1365-246X.2003.01939.x

[34] Viti, M., De Luca, J., Babbucci, D., Mantovani, E., Albarello, D. and D’Onza, F. (2004) Driving Mechanism of Tectonic Activity in the Northern Apennines: Quantitative Insights from Numerical Modeling. Tectonics, 23, TC4003. http://dx.doi.org/10.1029/2004tc001623

[35] Viti, M., Mantovani, E., Cenni, N. and Vannucchi, A. (2012) Post-Seismic Relaxation: An Example of Earthquake Triggering in the Apennine Belt (1915-1920). Journal of Geodynamics, 61, 57-67. http://dx.doi.org/10.1016/j.jog.2012.07.002

[36] Viti, M., Mantovani, E., Cenni, N. and Vannucchi, A. (2013) Interaction of Seismic Sources in the Apennine Belt. Physics and Chemistry of the Earth, Parts $A / B / C, 63,25-35$. http://dx.doi.org/10.1016/j.pce.2013.03.005

[37] Mantovani, E., Viti, M., Babbucci, D., Albarello, D., Cenni, N. and Vannucchi, A. (2010) Long-Term Earthquake Triggering in the Southern and Northern Apennines. Journal of Seismology, 14, 53-65. http://dx.doi.org/10.1007/s10950-008-9141-Z

[38] Mantovani, E., Viti, M., Babbucci, D., Cenni, N., Tamburelli, C. and Vannucchi, A. (2012) Middle Term Prediction of Earthquakes in Italy: Some Remarks on Empirical and Deterministic Approaches. Bollettino di Geofisica Teorica ed Applicata, 53, 89-111. 
[39] Mantovani, E., Viti, M., Babbucci, D., Cenni, N., Tamburelli, C., Vannucchi, A., Falciani, F., Fianchisti, G., Baglione, M., D’Intinosante, V. and Fabbroni, P. (2012) Potenzialità sismica della Toscana e definizione di criteri per interventi di prevenzione. Regione Toscana. Centro stampa Giunta Regione Toscana, Firenze, 140.

[40] Gasperini, P., Bernardini, G., Valensise, G. and Boschi, E. (1999) Defining Seismogenic Sources from Historical Earthquake Felt Reports. Bulletin of the Seismological Society of America, 89, 94-110.

[41] Guidoboni, E. and Comastri, A. (2005) Catalogue of Earthquakes and Tsunamis in the Mediterranean Area from the 11 th to the 15th Century. Istituto Nazionale di Geofisica e Vulcanologia, Roma, 1037.

[42] Cello, G., Mazzoli, S. and Tondi, E. (1998) The Crustal Fault Structure Responsible for the 1703 Earthquake Sequence of Central Italy. Journal of Geodynamics, 26, 443-460. http://dx.doi.org/10.1016/S0264-3707(97)00051-3

[43] Viti, M., Mantovani, E., Babbucci, D., Cenni, N. and Tamburelli, C. (2015) Where the Next Strong Earthquake in the Italian Peninsula? Insights by a Deterministic Approach. Bollettino di Geofisica Teorica ed Applicata, Special Issue. (in press)

[44] Galadini, F. (1999) Pleistocene Change in the Central Apennine Fault Kinematics, a Key to Decipher Active Tectonics in Central Italy. Tectonics, 18, 877-894. http://dx.doi.org/10.1029/1999TC900020

[45] Ambrosetti, P., Carboni, M.G., Conti, M.A., Costantini, A., Esu, D., Gandin, A., Girotti, O., Lazzarotto, A., Mazzanti, R., Nicosia, U., Parisi, G. and Sandrelli, F. (1979) Evoluzione Paleogeografica e Tettonica nei Bacini Tosco-UmbroLaziali nel Pliocene e nel Pleistocene Inferiore. Memorie della Società Geologica Italiana, 19, 573-580.

[46] Bartolini, C., Bernini, M., Carloni, G.C., Costantini, A., Federici, P.R., Gasperi, G., Lazzarotto, A., Marchetti, G., Mazzanti, R., Papani, G., Pranzini, G., Rau, A., Sandrelli, F., Vercesi, P.L., Castaldini, D. and Francavilla, F. (1983) Carta Neotettonica dell'Appennino Settentrionale. Note Illustrative. Bollettino della Società Geologica Italiana, 101, 523-549.

[47] Martini, I.P. and Sagri, M. (1993) Tectono-Sedimentary Characteristics of Late Miocene-Quaternary Extensional Basins of the Northern Apennines, Italy. Earth-Science Reviews, 34, 197-133. http://dx.doi.org/10.1016/0012-8252(93)90034-5

[48] Peccerillo, A. (2005) Plio-Quaternary Volcanism in Italy. Petrology, Geochemistry, Geodynamics. Springer-Verlag, Berlin-Heidelberg, 365.

[49] Acocella, V., Salvini, F., Funiciello, R. and Faccenna, C. (1999) The Role of Transfer Structures on Volcanic Activity at Campi Flegrei (Southern Italy). Journal of Volcanology and Geothermal Research, 91, 123-139. http://dx.doi.org/10.1016/S0377-0273(99)00032-3

[50] Tamburelli, C., Babbucci, D. and Mantovani, E. (2000) Geodynamic Implications of Subduction Related Magmatism: Insights from the Tyrrhenian-Apennines Region. Journal of Volcanology and Geothermal Research, 104, 33-43. http://dx.doi.org/10.1016/S0377-0273(00)00198-0

[51] Gudmundsson, A. (2001) Fluid Overpressure and Flow in Fault Zones: Field Measurements and Models. Tectonophysics, 336, 183-197. http://dx.doi.org/10.1016/S0040-1951(01)00101-9

[52] Acocella, V. and Funiciello, R. (2006) Transverse Systems along the Extensional Tyrrhenian Margin of Central Italy and Their Influence on Volcanism. Tectonics, 25, TC2003. http://dx.doi.org/10.1029/2005tc001845

[53] Ghisetti, F. and Vezzani, L. (1999) Depth and Modes of Pliocene-Pleistocene Crustal Extension of the Apennines (Italy). Terra Nova, 11, 67-72. http://dx.doi.org/10.1046/j.1365-3121.1999.00227.x

[54] Marroni, M., Molli, G., Ottria, G. and Pandolfi, L. (2001) Tectono-Sedimentary Evolution of the External Liguride Units (Northern Apennines, Italy): Insights in the Pre-collisional History of a Fossil Ocean-Continent Transition Zone. Geodinamica Acta, 14, 307-320. http://dx.doi.org/10.1080/09853111.2001.11432449

[55] Molli, G. (2008) Northern Apennine-Corsica Orogenic System: An Updated Overview. Geological Society, London, Special Publications, 298, 413-442. http://dx.doi.org/10.1144/SP298.19

[56] Cerrina Feroni, A., Martelli, L., Martinelli, P., Ottria, G. and Sarti, G. (2001) The Romagna Apennines, Italy: An Eroded Duplex. Geological Journal, 36, 39-54. http://dx.doi.org/10.1002/gj.874

[57] Balestrieri, M.L., Bernet, M., Brandon, M.T., Picotti, V., Reiners, P. and Zattin, M. (2003) Pliocene and Pleistocene Exhumation and Uplift of Two Key Areas of the Northern Apennines. Quaternary International, 101-102, 67-73. http://dx.doi.org/10.1016/S1040-6182(02)00089-7

[58] Boccaletti, M., Corti, G. and Martelli, L. (2010) Recent and Active Tectonics of the External Zone of the Northern Apennines (Italy). International Journal of Earth Sciences (Geologische Rundschau), 100, 1331-1348. http://dx.doi.org/10.1007/s00531-010-0545-y

[59] Ambrosetti, P., Bosi, C., Carraro, F., Ciaranfi, N., Panizza, M., Papani, G., Vezzani, L. and Zanferrari, A. (1987) Neotectonic Map of Italy: Scale 1:500000. Consiglio Nazionale delle Ricerche, Progetto Finalizzato Geodinamica, Sottoprogetto Neotettonica. Litografia Artistica Cartografica, Florence (Italy). 
[60] Meisina, C. and Piccio, A. (2003) River Dynamics and Slope Processes along a Sector of the Villalvernia-Varzi Line (Northern Italy). Quaternary International, 101-102, 179-190. http://dx.doi.org/10.1016/S1040-6182(02)00100-3

[61] Panini, F., Fioroni, C. and Fregni, P. (2004) Geologia dell'Area di Varzi (Appennino Vogherese): Note Preliminari. Atti Ticinensi di Scienze della Terra, 45, 43-59.

[62] Elter, F.M., Elter, P., Eva, C., Eva, E., Kraus, R.K., Padovano, M. and Solarino, S. (2012) An Alternative Model for the Recent Evolution of Northern-Central Apennines (Italy). Journal of Geodynamics, 54, 55-63. http://dx.doi.org/10.1016/j.jog.2011.11.001

[63] Mantelli, L. and Vercesi, P.L. (2000) Evoluzione Morfostrutturale Recente del Pedeappennino Vogherese-Tortonese. Atti Ticinensi di Scienze della Terra, 41, 49-58.

[64] Benedetti, L., Tapponnier, P., Gaudemer, Y., Manighetti, I. and Van der Woerd, J. (2003) Geomorphic Evidence for an Emergent Active Thrust Along the Po Plain: The Broni-Stradella Fault. Journal of Geophysical Research, 108, 2238. http://dx.doi.org/10.1029/2001jb001546

[65] Toscani, G., Seno, S., Fantoni, R. and Rogledi, S. (2006) Geometry and Timing of Deformation Inside a Structural Arc: the Case of the Western Emilian Folds (Northern Apennines Front, Italy). Bollettino della Società Geologica Italiana, 125, 59-65.

[66] Bernini, M. and Papani, G. (1987) Alcune Considerazioni sulla Struttura del Margine Appenninico Emiliano fra lo Stirone e l'Enza (e Sue Relazioni con il Sistema del F. Taro). L'Ateneo Parmense-Acta Naturalia, 23, 219-240.

[67] Vescovi, P. (1988) La Linea Trasversale Passo della Cisa-Val Parma-Bassa Val d'Enza: 1. Sistema Trascorrente Sinistro nella Zona del Passo della Cisa (Prov. di Parma). L'Ateneo Parmense-Acta Naturalia, 24, 221-243.

[68] Boccaletti, M. and Martelli, L. (a cura di) (2004) Carta Sismo-tettonica della Regione Emilia-Romagna, Scala 1:250.000 e Note Illustrative. SELCA, Firenze.

[69] Vannoli, P., Burrato, P. and Valensise, G. (2014) The Seismotectonics of the Po Plain (Northern Italy): Tectonic Diversity in a Blind Faulting Domain. Pure and Applied Geophysics, 172, 1105-1142.

[70] Mantovani, E., Viti, M., Babbucci, D., Cenni, N., Tamburelli, C., Vannucchi, A., Falciani, F., Fianchisti, G., Baglione, M., D'Intinosante, V., Fabbroni, P., Martelli, L., Baldi, P. and Bacchetti, M. (2013) Assetto Tettonico e Potenzialità Sismica dell'Appennino Tosco-Emiliano-Romagnolo e Val Padana. Regione Toscana e Regione Emilia-Romagna. Centro Stampa Regione Emilia-Romagna, pp. 168.

[71] Bartole, R. (1995) The North Tyrrhenian-Northern Apennines Post Collisional System: Constraints for a Geodynamical Model. Terra Nova, 7, 7-30. http://dx.doi.org/10.1111/j.1365-3121.1995.tb00664.x

[72] Elter, P., Giglia, G., Tongiorgi, M. and Trevisan, L. (1975) Tensional and Compressional Areas in the Recent (Tortonian to Present) Evolution on Northern Apennines. Bollettino di Geofisica Teorica ed Applicata, 65, 3-18.

[73] Pascucci, V., Martini, I.P., Sagri, M. and Sandrelli, F. (2007) Effects of Transverse Structural Lineaments on the Neogene-Quaternary Basins of Tuscany (Inner Northern Apennines, Italy). In: Nichols, G., Williams, E. and Paola, C., Eds., Sedimentary Processes, Environments and Basins: A Tribute to Peter Fried, International Association of Sedimentology, Special Publ. No. 38, 155-182. http://dx.doi.org/10.1002/9781444304411.ch8

[74] Compagnoni, B. and Galluzzo, F. (2004) Geological Map of Italy 1:250.000 Scale. Especially Printed for the 32nd International Geological Congress, SELCA, Florence, 20-28 August 2004.

[75] Brogi A. (2011) Bowl-Shaped Basin Related to Low-Angle Detachment during Continental Extension: The Case of the Controversial Neogene Siena Basin (Central Italy, Northern Apennines). Tectonophysics, 499, 54-76. http://dx.doi.org/10.1016/j.tecto.2010.12.005

[76] Bonini, M., Sani, F., Stucchi, E.M., Moratti, G., Benvenuti, M., Menanno, G. and Tanini, C. (2014) Late Miocene Shortening of the Northern Apennines Back-Arc. Journal of Geodynamics, 74, 1-31. http://dx.doi.org/10.1016/j.jog.2013.11.002

[77] Boschian, G., Bossio, A., Dall'Antonia, B. and Mazzanti, R. (2006) Il Quaternario della Toscana Costiera. Studi Costieri, 12, 1-207.

[78] Bossio, A., Costantini, A., Foresi, L.M., Lazzarotto, A., Liotta, D., Mazzanti, R., Mazzei, R., Salvatorini, G. and Sandrelli, F. (1996) Studi Preliminari sul Sollevamento della Toscana Meridionale dopo il Pliocene Medio. Studi Geologici Camerti, 1, 87-91.

[79] Bossio, A., Costantini, A., Foresi, L.M., Lazzarotto, A., Mazzanti, R., Mazzei, R., Pascucci, V., Salvatorini, G., Sandrelli, F., and Terzuoli, A. (1998) Neogene-Quaternary Sedimentary Evolution in the Western Side of the Northern Apennines (Italy). Memorie della Società Geologica Italiana, 52, 513-525.

[80] Benvenuti, M., Del Conte, S., Scarselli, N. and Dominici, S. (2014) Hinterland Basin Development and Infilling through Tectonic and Eustatic Processes: Latest Messinian-Gelasian Valdelsa Basin, Northern Apennines, Italy. Basin Research, 26, 387-402. http://dx.doi.org/10.1111/bre.12031 
[81] Brogi, A., Capezzuoli, E., Buracchi, E. and Branca, M. (2012) Tectonic Control on Travertine and Calcareous Tufa Deposition in a Low-Temperature Geothermal System (Sarteano, Central Italy). Journal of the Geological Society, 169, 461-476. http://dx.doi.org/10.1144/0016-76492011-137

[82] Sani, F., Moratti, G., Bonini, M., Landi, B., Tanini, C., Piccardi, L. and Menichetti, B. (2001) A Transect in Southern Tuscany, from Baccinello Basin to the Cetona Ridge. Proceedings of the Meeting "EL.I.C.A. 97, The Elba Island: A Key Puzzle Linking the Corso-Sardinian Massif and Adria”, Portoferraio (Livorno, Italy), 22-24 September 1997, Post-Congress Excursion Guide, 25-26 September 1997. Ofioliti, 26, 381-400.

[83] Barberi, F., Buonasorte, G., Cioni, R., Fiordelisi, A., Foresi, L., Iaccarino, S., Laurenzi, M.A., Sbrana, A., Vernia, L. and Villa, I.M. (1994) Plio-Pleistocene Geological Evolution of the Geothermal Area of Tuscany and Latium. Memorie Descrittive della Carta Geologica d'Italia, 49, 77-134.

[84] Benvenuti, M. and Papini, M. (1997) Depositi Continentali Plio-Pleistocenici nell'area di Monte Giovi. Relazioni tra l'Evoluzione Idrografica e la Tettonica della Valdisieve (Firenze). Il Quaternario, 10, 105-120.

[85] Coltorti, M, Ravani, S. and Verrazzani, F. (2007) The Growth of the Chianti Ridge: Progressive Unconformities and Depositional Sequences in the S. Barbara Basin (Upper Valdarno, Italy). Il Quaternario, 20, 67-84.

[86] Bianchi, I., Piana Agostinetti, N., De Gori, P., Chiarabba, C. (2008) Deep Structure of the Colli Albani Volcanic District (Central Italy) from Receiver Functions Analysis. Journal of Geophysical Research, 113, B09313. http://dx.doi.org/10.1029/2007jb005548

[87] Capezzuoli, E. (2013) Il Patrimonio di Travertini e Calcareous Tufa in Toscana. Rendiconti Online della Società Geologica Italiana, 27, 31-41. http://dx.doi.org/10.3301/rol.2013.18

[88] Ghinassi, M., Magi, M., Sagri, M. and Singer, B.S. (2004) Arid Climate 2.5 Ma in the Plio-Pleistocene Valdarno Basin (Northern Apennines, Italy). Palaegeography Palaeoclimatology Palaeoecology, 207, 37-57. http://dx.doi.org/10.1016/j.palaeo.2004.01.020

[89] Aldinucci, M., Ghinassi, M. and Sandrelli, F. (2007) Climatic and Tectonic Signature in the Fluvial Infill of a Late Pliocene Valley (Siena Basin, Northern Apennines, Italy). Journal of Sedimentary Research, 77, 398-414. http://dx.doi.org/10.2110/jsr.2007.039

[90] Boscato, P., Coltorti, M. and Reggiani, P. (2008) Pliocene Anancus arvernensis (Croizet \& Jobert, 1828) Remains from Cetona (Siena): Stratigraphy, Chronology and Paleoenvironment. Bollettino della Società Geologica Italiana, 127, 151-162.

[91] Bartolini, C. and Pranzini, G. (1981) Plio-Quaternary Evolution of the Arno Basin Drainage. Zeitschrift für Geomorphologie N.F., Supplement, 40, 77-91.

[92] Bartolini, C. and Pranzini, G. (1988) Evoluzione dell'Idrografia nella Toscana Centro Settentrionale. Bollettino del Museo di Storia Naturale della Lunigiana, 6-7, 79-83.

[93] Bonini, M. and Sani, F. (1993) Analisi Strutturale dei Depositi Pleistocenici dell'Area di Firenze e di Rignano sull'Arno (Valdarno Superiore), con Considerazioni Generali sulle Deformazioni Quaternarie dell'Appennino Settentrionale. Bollettino della Società Geologica Italiana, 112, 573-593.

[94] Briganti, R., Ciufegni, A., Coli, M., Polimeni, S. and Pranzini, G. (2003) Underground Florence: Plio-Quaternary Geological Evolution of the Florence Area. Bollettino della Società Geologica Italiana, 12, 435-445.

[95] Coli, M. and Rubellini, P. (2013) Geological Anamnesis of the Florence Area, Italy [Eine Geologische Anamnese von Florenz, Italien.]. Zeitschrift der Deutschen Gesellschaft für Geowissenschaften, 164, 581-589. http://dx.doi.org/10.1127/1860-1804/2013/0042

[96] Costantini, A., Mazzanti, R. and Sandrelli F. (1995) La Val d'Ambra, Appendice del Lago del Valdarno Superiore nel Pleistocene Medio e Attuale Punto di Contatto Incerto nello Spartiacque tra i Bacini dell'Arno e dell'Ombrone. Atti della Società Toscana di Scienze Naturali, Mem.-Serie A, 102, 177-184.

[97] Fidolini, F., Ghinassi, M., Aldinucci, M., Billi, P., Boaga, J., Deiana, R. and Brivio, L. (2013) Fault-Sourced Alluvial Fans and Their Interaction with Axial Fluvial Drainage: An Example from the Plio-Pleistocene Upper Valdarno Basin (Tuscany, Italy). Sedimentary Geology, 289, 19-39. http://dx.doi.org/10.1016/j.sedgeo.2013.02.004

[98] Bianchi, V., Ghinassi, M., Aldinucci, M., Boaga, J., Brogi, A. and Deiana, R. (2015) Tectonically Driven Deposition and Landscape Evolution within Upland Incised Valleys: Ambra Valley Fill, Pliocene-Pleistocene, Tuscany, Italy. Sedimentology, 62, 897-927. http://dx.doi.org/10.1111/sed.12165

[99] Brogi, A., Capezzuoli, E., Aquè, R., Branca, M. and Voltaggio, M. (2010) Studying Travertines for Neotectonics Investigations: Middle-Late Pleistocene Syn-Tectonic Travertine Deposition at Serre di Rapolano (Northern Apennines, Italy). International Journal of Earth Sciences, 99, 1383-1398. http://dx.doi.org/10.1007/s00531-009-0456-y

[100] Brogi A. (2011) Variation in Fracture Patterns in Damage Zones Related to Strike-Slip Faults Interfering with Pre-Existing Fractures in Sandstone (Calcione Area, Southern Tuscany, Italy). Journal of Structural Geology, 33, 644-661. http://dx.doi.org/10.1016/j.jsg.2010.12.008 
[101] Bossio, A., Mazzei, R., Salvatorini, G. and Sandrelli, F. (2000-2002) Geologia dell’Area Compresa tra Siena e Poggibonsi ("Bacino del Casino"). Atti della Società Toscana di Scienze Naturali, Mem.-Serie A, 69-85.

[102] Brogi, A., Capezzuoli, E., Martini, I., Picozzi, M. and Sandrelli, F. (2014) Late Quaternary Tectonics in the Inner Northern Apennines (Siena Basin, Southern Tuscany, Italy) and Their Seismotectonic Implication. Journal of Geodynamics, 76, 25-45. http://dx.doi.org/10.1016/j.jog.2014.03.001

[103] Cornamusini, G., Ielpi, A., Bonciani, F., Callegari, I. and Conti, P. (2012) Geological Map of the Chianti Mts (Northern Apennines, Italy). Journal of Maps, 8, 22-32. http://dx.doi.org/10.1080/17445647.2012.668423

[104] Bartolini, C. and Pranzini, G. (1979) Dati Preliminari sulla Neotettonica dei Fogli 97 (S. Marcello Pistoiese), 105 (Lucca) E 106 (Firenze). Progetto Finalizzato Geodinamica, Sottoprogetto Neotettonica, Pubbl. No. 251, 481-453.

[105] Boccaletti, M., Corti, G., Gasperini, P., Piccardi, L., Vannucci, G. and Clemente, S. (2001) Active Tectonics and Seismic Zonation of the Urban Area of Florence, Italy. Pure and Applied Geophysics, 158, 2313-2332. http://dx.doi.org/10.1007/PL00001172

[106] Castello, B., Selvaggi, G., Chiarabba, C. and Amato, A. (2006) CSI Catalogo Della Sismicità Italiana 1981-2002, Versione 1.1, INGV-CNT, Roma. http://csi.rm.ingv.it/

[107] ISIDe Working Group (2010) Italian Seismological Instrumental and Parametric Database. http://iside.rm.ingv.it

[108] Basili, R. and Bosi, C. (1996) Morfo-Litostratigrafia dell'Area Romana in Sinistra Tevere. Il Quaternario, 9, $273-280$.

[109] Mancini, M., Girotti, O. and Cavinato, G.P. (2003-2004) Il Pliocene e il Quaternario della Media Valle del Tevere (Appennino Centrale). Geologica Romana, 37, 175-236.

[110] Coltorti, M., Firuzabadi, D. and Pieruccini, P. (2011) Geomorphological Map and Land Units at 1:200,000 Scale of the Siena Province (Southern Tuscany, Italy). Journal of Maps, 7, 536-551. http://dx.doi.org/10.4113/jom.2011.1193

[111] Nisi, M.F., Antonioli, F., Pra, G.D., Leoni, G. and Silenzi S. (2003) Coastal Deformation between the Versilia and the Garigliano Plains (Italy) Since the Last Interglacial Stage. Journal of Quaternary Science, 18, 709-721. http://dx.doi.org/10.1002/jqs.803

[112] De Rita, D., Fabbri, M. and Cimarelli, C. (2004) Evoluzione Pleistocenica del Margine Tirrenico dell'Italia Centrale tra Eustatismo, Vulcanismo e Tettonica. Il Quaternario, 17, 523-536.

[113] Pandeli, E., Bartolini. C., Dini, A. and Antolini, E. (2010) New Data on the Paleogeography of Southern Tuscany (Italy) Since Late Miocene Time. International Journal of Earth Sciences, 99, 1357-1381. http://dx.doi.org/10.1007/s00531-009-0463-z

[114] Acocella, V. (2000) Space Accommodation by Roof Lifting During Pluton Emplacement at Amiata (Italy). Terra Nova, 12, 149-155. http://dx.doi.org/10.1046/j.1365-3121.2000.00286.x

[115] Finetti, I.R. (2006) Basic Regional Crustal Setting and Superimposed Local Pluton Intrusion Related Tectonics in the Larderello-Monte Amiata Geothermal Province from Integrated CROP Seismic Data. Bollettino della Società Geologica Italiana, 125, 117-146.

[116] Cerrina Feroni, A., Da Prato, S., Doveri, M., Ellero, A., Lelli, M., Marini, L., Masetti, G., Nisi, B. and Raco, B. (2010) Geological, Hydrogeological and Hydrogeochemical Characterization of Significant Subterranean Water Bodies of the Tuscany Region (SSWB): 32CT010 "Coastal Aquifer between the Cecina River and San Vincenzo", 32CT030 "Coastal Aquifer between the Fine River and Cecina River", 32CT050 "Aquifer of the Cecina Valley". Memorie descrittive della Carta Geologica d'Italia, 89, 5-80.

[117] Ciampalini, A., Consoloni, I. and Sarti, G. (2011) Fault Array Evolution in Extensional Basins: Insights from Statistical Analysis of Gravel Deposits in the Cecina River (Tuscany, Italy). Sedimentology, 58, 1895-1913. http://dx.doi.org/10.1111/j.1365-3091.2011.01244.x

[118] Cerrina Feroni, A., Bonini, M., Martinelli, P., Moratti, G., Sani, F., Montanari, D. and Del Ventisette, C. (2006) Lithological Control on Thrust-Related Deformation in the Sassa-Guardistallo Basin (Northern Apennines Interland, Italy). Basin Research, 18, 301-321. http://dx.doi.org/10.1111/j.1365-2117.2006.00295.x

[119] Brogi, A. and Fabbrini, L. (2009) Extensional and Strike-Slip Tectonics across the Monte Amiata-Monte Cetona Transect (Northern Apennines, Italy) and Seismotectonic Implications. Tectonophysics, 476, 195-209. http://dx.doi.org/10.1016/j.tecto.2009.02.020

[120] Brogi, A., Liotta, D., Meccheri, M. and Fabbrini, L. (2010) Transtensional Shear Zones Controlling Volcanic Eruptions: the Middle Pleistocene Mt. Amiata Volcano (Inner Northern Apennines, Italy). Terra Nova, 22, 137-146. http://dx.doi.org/10.1111/j.1365-3121.2010.00927.x

[121] Dini, I., Ceccarelli, A., Brogi, A., Giorgi, N., Galleni, P. and Rossi, L. (2010) Geological Evaluation of the Base of the Mt. Amiata Volcanic Complex (Tuscany, Italy). Proceedings of World Geothermal Congress, Bali, 25-29 April 2010, $1-9$. 
[122] Bonazzi, U., Fazzini, P. and Gasperi, G. (1992) Note alla Carta Geologica del Fiume Albegna. Bollettino della Società Geologica Italiana, 111, 341-354.

[123] Martelli, L., Moratti, G. and Sani, F. (1989) Analisi Strutturale dei Travertini della Toscana Meridionale (Valle dell'Albegna). Bollettino della Società Geologica Italiana, 108, 197-205.

[124] Herring, T.A., King, R.W. and McClusky, S.C. (2010) GAMIT Reference Manual, GPS Analysis at MIT, Release 10.4. Department of Earth, Atmospheric and Planetary Sciences, Massachusset Institute of Technology, Cambridge, USA.

[125] Dong, D., Herring, T.A. and King, R.W. (1998) Estimating Regional Deformation from a Combination of Space and Terrestrial Geodetic Data. Journal of Geodesy, 72, 200-214. http://dx.doi.org/10.1007/s001900050161

[126] Herring, T.A., King, R.W. and McClusky, S.C. (2010) Global Kalman Filter VLBI and GPS Analysis Program, GLOBK Reference Manual, Release 10.4. Department of Earth, Atmospheric and Planetary Sciences, Massachusetts Institute of Technology, Cambridge, USA.

[127] Altamimi, Z., Métivier, L. and Collilieux, X. (2012) ITRF2008 Plate Motion Model. Journal of Geophysical Research, 117, B07402. http://dx.doi.org/10.1029/2011jb008930

[128] Cenni, N., Viti, M., Baldi, P., Mantovani, E., Bacchetti, M. and Vannucchi, A. (2013) Present Vertical Movements in Central and Northern Italy from GPS Data: Possible Role of Natural and Anthropogenic Causes. Journal of Geodynamics, 71, 74-85. http://dx.doi.org/10.1016/j.jog.2013.07.004

[129] Blewitt, G. and Lavallée, D. (2002) Effect of Annual Signals on Geodetic Velocity. Journal of Geophysical Research, 107, 2145. http://dx.doi.org/10.1029/2001JB000570

[130] Bos, M.S., Fernandes, R.M.S., Williams, S.D.P. and Bastos, L. (2008) Fast Error Analysis of Continuous GPS Observations. Journal of Geodesy, 82, 157-166. http://dx.doi.org/10.1007/s00190-007-0165-x

[131] Hackl, M., Malservisi. R., Hugentobler, U. and Wonnacott, R. (2011) Estimation of Velocity Uncertainties from GPS Time Series: Examples from the Analysis of the South African Trignet Network. Journal of Geophysical Research, 116, B11404. http://dx.doi.org/10.1029/2010jb008142 